\title{
Experimental Emissions and Fuel Economy Analysis of a Diesel Engine Operating on Vegetable Oil
}

\author{
Robert F. Minehart III \\ West Virginia University
}

Follow this and additional works at: https://researchrepository.wvu.edu/etd

\section{Recommended Citation}

Minehart, Robert F. III, "Experimental Emissions and Fuel Economy Analysis of a Diesel Engine Operating on Vegetable Oil" (2012). Graduate Theses, Dissertations, and Problem Reports. 4896.

https://researchrepository.wvu.edu/etd/4896

This Thesis is protected by copyright and/or related rights. It has been brought to you by the The Research Repository @ WVU with permission from the rights-holder(s). You are free to use this Thesis in any way that is permitted by the copyright and related rights legislation that applies to your use. For other uses you must obtain permission from the rights-holder(s) directly, unless additional rights are indicated by a Creative Commons license in the record and/ or on the work itself. This Thesis has been accepted for inclusion in WVU Graduate Theses, Dissertations, and Problem Reports collection by an authorized administrator of The Research Repository @ WVU. For more information, please contact researchrepository@mail.wvu.edu. 
Experimental Emissions and Fuel Economy Analysis of a Diesel Engine Operating on Vegetable Oil

\author{
Robert F. Minehart III \\ Thesis submitted to the \\ College of Engineering and Mineral Resources \\ at West Virginia University \\ in partial fulfillment of the requirements \\ for the degree of \\ Master of Science \\ in \\ Mechanical Engineering \\ Mridul Gautam, Ph.D., Chair \\ Greg Thompson, Ph.D. \\ Alfred Stiller, Ph.D. \\ Department of Mechanical and Aerospace Engineering \\ Morgantown, West Virginia
}

2012

Keywords: Diesel; Biofuels; Vegetable Oil; Emissions 


\title{
Experimental Emission and Fuel Economy Analysis of a Diesel Engine Operating On Vegetable Oil
}

\author{
Robert F. Minehart III
}

\begin{abstract}
Plant based oils or vegetable oils (VO) may be an alternate fuel to diesel for heavy duty diesel applications. The object of this study was to compare the emissions and fuel economy of a diesel engine operated on both diesel fuel and VO. This was achieved by experimentally comparing the soot and gaseous exhaust emissions from a diesel engine that was operated on both VO and diesel fuel. A 1.9L GM/Vauxhall diesel engine was mounted on an Eaton $225 \mathrm{HP}$ AC Engine Dynamometer. The engine's soot production output was measured using an AVL 483 Micro Soot Sensor and the gaseous exhaust emissions were analyzed using a HORIBA Mexa 7200-D. Tests were conducted at six steady state test modes of different engine speeds and loads. It was determined that the engine exhaust emissions was similar for both VO and diesel fuel. However, the soot production for VO was higher under maximum load and high speed testing conditions. This study suggests that VO is an effective substitute for diesel fuel. However, it must be noted that these tests were conducted using a warm engine. The high viscosity of $\mathrm{VO}$ at low temperatures offers engine design challenges. These challenges may be overcome by using aftermarket conversion kits.
\end{abstract}




\section{Acknowledgements}

I would like to thank the following members of my committee: Dr. Mridul Gautam, Dr. Alfred Stiller, and Dr. Greg Thompson for their dedicated time and assistance. I would like to give special recognition to Dr. Gautam for giving me the opportunity to pursue this research, and providing his guidance that made it possible to earn my Master's degree. Likewise, I express my sincere appreciation to Dr. Stiller for his support and guidance throughout both my undergraduate and graduate studies at WVU.

Thank you to the CAFEE and graduate students who helped me along the way. None of this would have been possible without their expert knowledge, comment to helping, and guidance. It is impossible to recognize all WVU faculty and staff who have helped me through my years at WVU - they were wonderful and I sincerely appreciate the opportunity I have learned from each of them.

I want to thank my family for being with me every step of the way; including, my father who guided my early engineering efforts, and my mother who inspires me to do my best. I especially want to thank my wife, Tiffany, for her complete support, love, and understanding during this long process. Tiffany, I have finally made it and could not have done this without you.

Finally, with the greatest of respect, I recognize the leadership and staff of WVU. From my first day on campus, it was clear that they are absolutely dedicated to each student's success. It is their support that makes WVU great! 


\section{Table of Contents}

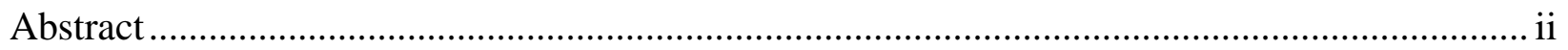

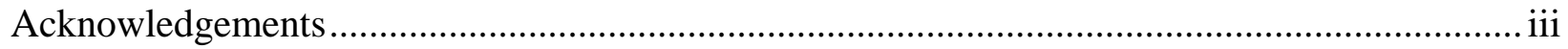

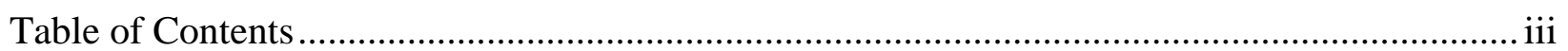

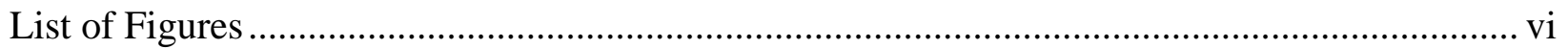

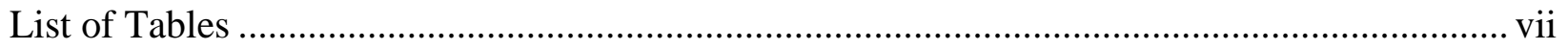

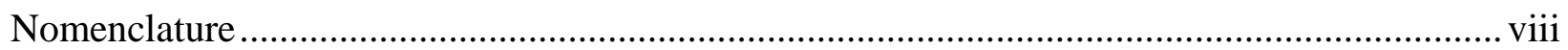

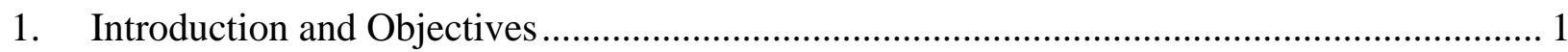

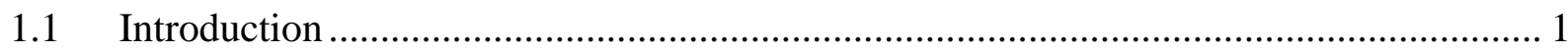

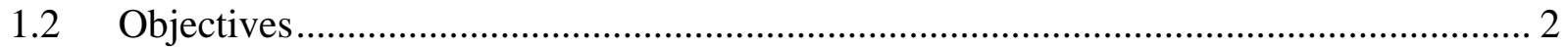

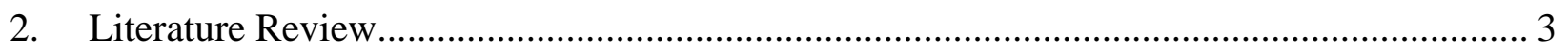

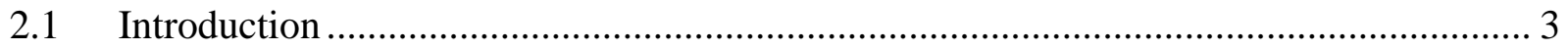

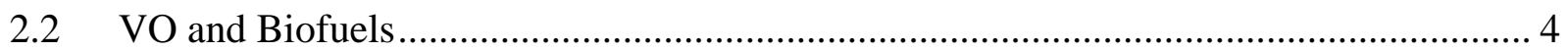

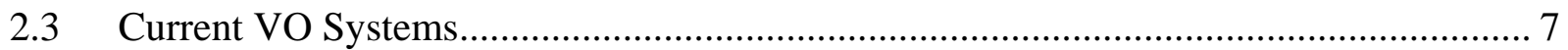

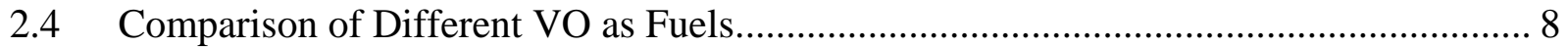

2.5 Emission Trends with VO Operation ........................................................................ 10

2.6 Major Benefits of Vegetable Oil Fuels .................................................................. 13

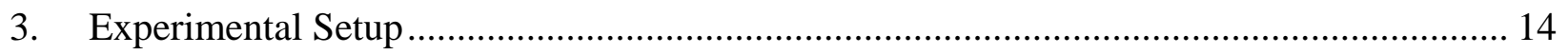

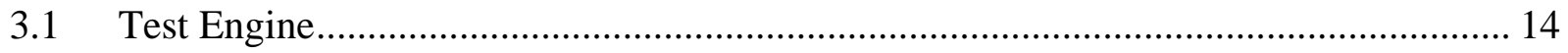

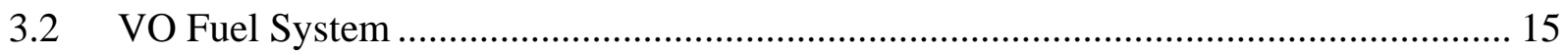

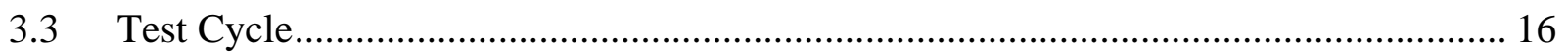

$3.4 \quad$ Laboratory Testing Setup ………………………................................................... 17

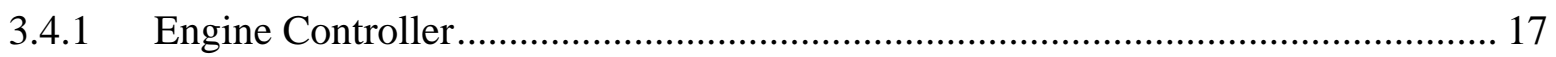




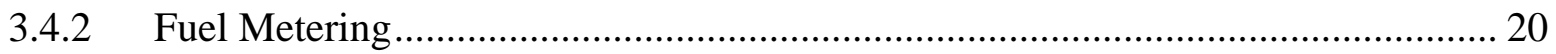

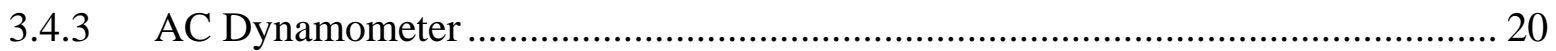

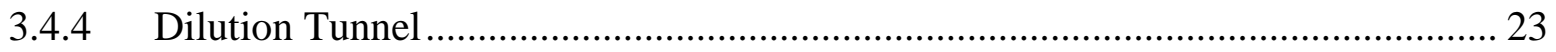

3.4.5 Gaseous Emissions Sampling System ……...................................................... 24

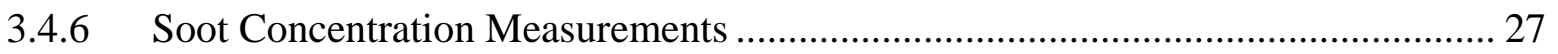

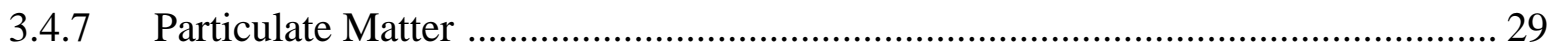

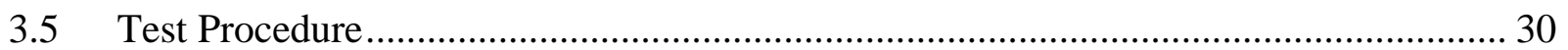

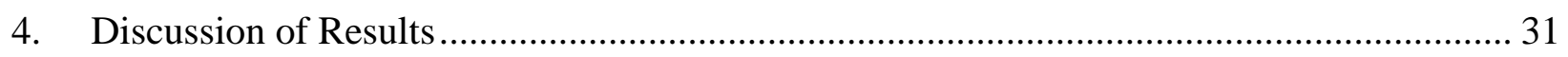

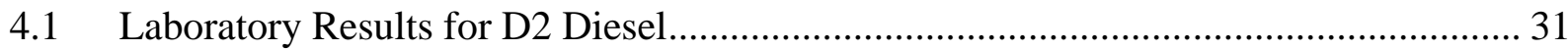

4.2 Laboratory Results for VO Fuel............................................................................ 32

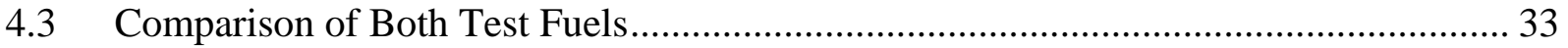

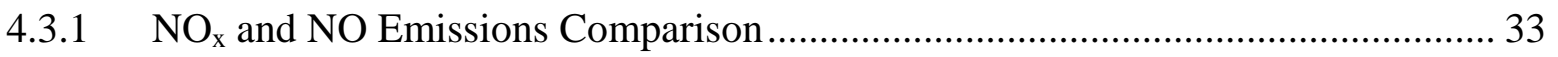

4.3.2 Measured Soot Emission Comparison ………………………………………....... 35

4.3.3 Other Regulated Constituents ( $\mathrm{THC}, \mathrm{CO}$, and $\mathrm{CO}_{2}$ ) Comparison.......................... 36

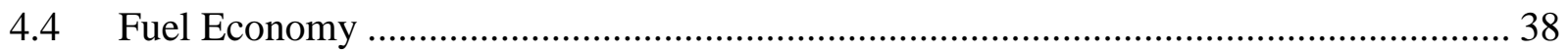

$4.5 \quad$ Exhaust Temperature Review …………………............................................................ 39

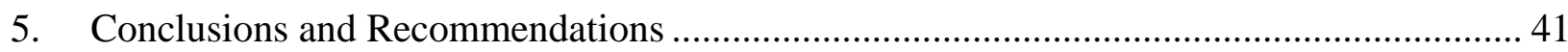

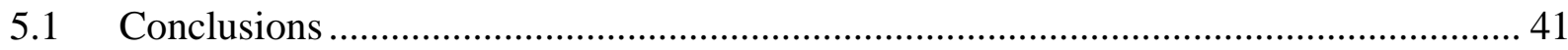

5.2 Recommendations ……………………………................................................ 42

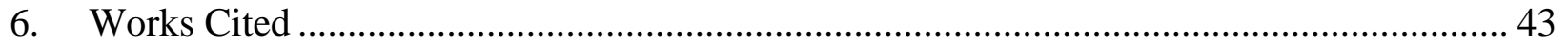

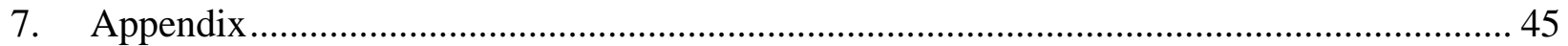




\section{List of Figures}

Figure 1: Two tank on demand VO system for Ford Powerstroke ....................................... 8

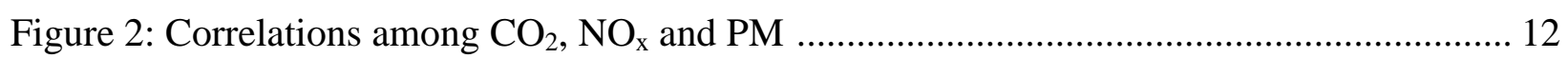

Figure 3: Engine Torque and Power Curves vs. Engine Speed .............................................. 15

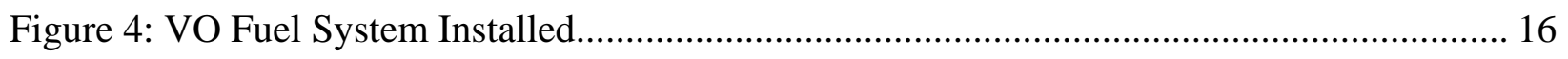

Figure 5: Engine Control System Diagram.................................................................. 18

Figure 6: ECU Breakout Connection Module ...................................................................... 19

Figure 7: NI and Drivven Control System................................................................. 19

Figure 8: Components of a Dynamometer......................................................................... 22

Figure 9: Example of a Test Engine Setup on Eaton 225 HP AC Engine Dynamometer ........... 22

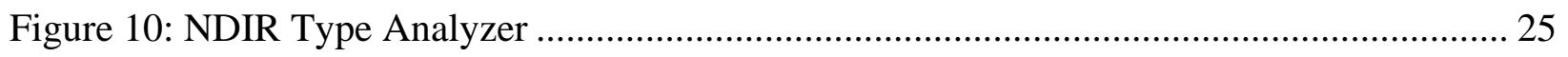

Figure 11: Diagram of FID Type Analyzer ....................................................................... 26

Figure 12: AVL Micro Soot Sensor Photo Acoustic Method ................................................ 28

Figure 13: AVL 483 Micro Soot Sensor.......................................................................... 29

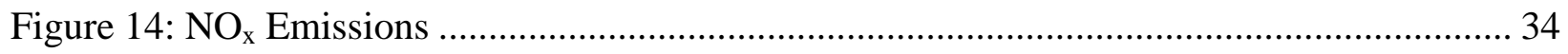

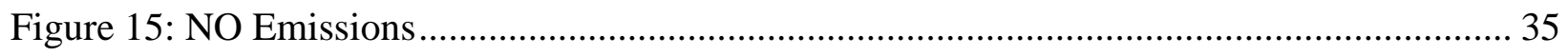

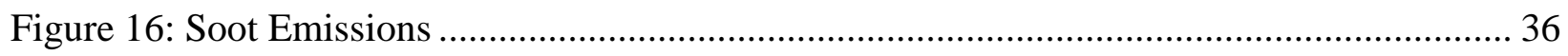

Figure 17: Brake-Specific Total Hydrocarbon Emissions ................................................. 37

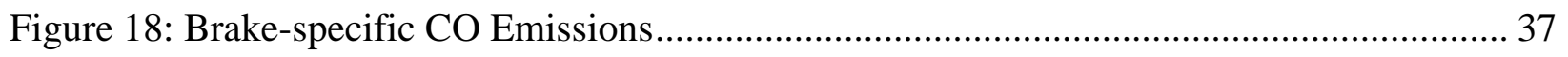

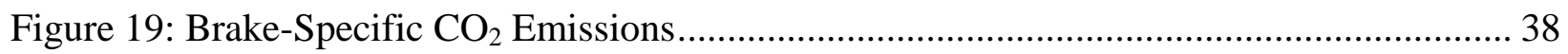

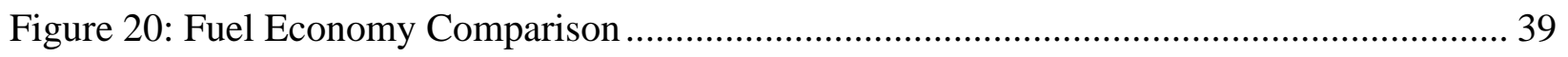




\section{List of Tables}

Table 1: Diesel fuel vs. Biodiesel ........................................................................................ 5

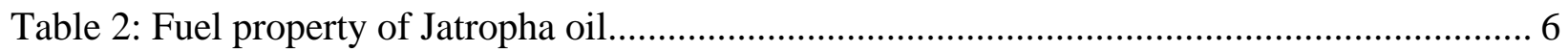

Table 3: Impact of VO on engine performance and durability ............................................ 9

Table 4: VW \#1 vs. VW \#2 VO Fuel to Diesel Fuel ........................................................... 11

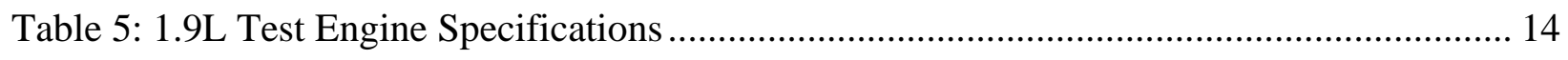

Table 6: POPDiesel System Test Matrix .......................................................................... 17

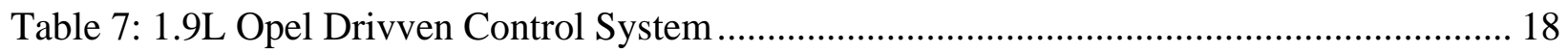

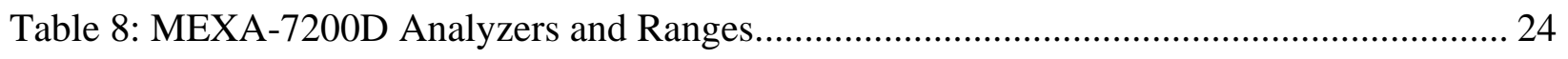

Table 9: Brake Specific Exhaust Emissions from Baseline D2 Diesel Runs ........................... 32

Table 10: Brake Specific Exhaust Emissions from VO Fuel Runs ........................................ 33

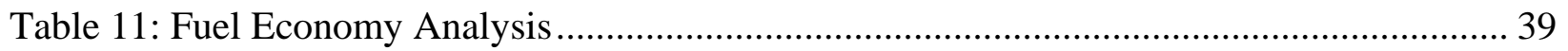

Table 12: Exhaust Temperature Measurements...........................................40 


\section{Nomenclature}

AC

CAFEE

CFR

$\mathrm{CO}$

$\mathrm{CO}_{2}$

CVS

D2

ECU

EERL

FID

GC

$\mathrm{HC}$

HVAC

IEA

NDIR

$\mathrm{NI}$

NIST

NO

$\mathrm{NO}_{\mathrm{x}}$

$\mathrm{NO}_{2}$

$\mathrm{O} 2$

$\mathrm{O} 3$

PM

RPM

THC

$\operatorname{Tr}$

US

VO

WVU
Alternating Current

Center for Alternative Fuels, Engines and Emissions

Code of Federal Regulations

Carbon Monoxide

Carbon Dioxide

Constant Volume Sampling

Ultra-Low-Sulfur Diesel

Engine Control Unit

Engine and Emissions Research Laboratory

Flame Ionization Detector

Gas Chromatograph

Hydrocarbons

Heating, Ventilation and Air Conditioning

International Energy Association

Non-Dispersive Infrared Analyzer

National Instruments

National Institute for Standards and Technology

Nitric Oxide

Oxides of Nitrogen

Nitrogen Dioxide

Oxygen

Ozone

Particulate Matter

Revolutions per Minute

Total Hydrocarbons

Transmittance Ratio

United States

Vegetable Oil

West Virginia University 


\section{Introduction and Objectives}

\subsection{Introduction}

It has been suggested that a diversification of energy sources may help mitigate future world fuel shortages [1]. Examples of this diversification are apparent in Europe where approximately $62 \%$ of the energy and power facilities being built utilize renewable sources (solar, wind, biomass, etc.); while $45 \%$ of current electrical power is supplied by nuclear and hydro power stations [2]. Efforts to reduce vehicle reliance on fossil fuels are globally apparent by the increasing selection of hybrid electric and highly efficient, clean burning diesel vehicles. However, even with such advancements, only $2 \%$ of global transportation relies on alternate fuels. The International Energy Association (IEA) has developed a goal to have 27\% of vehicles, worldwide, operating on biofuels by 2050 [3].

Plant based oils, or vegetable oils (VO), have the potential to be a future alternate fuel source. The focus of this study is to examine the exhaust emissions and fuel economy of a diesel engine running on vegetable oil. Since the development of the internal combustion engine, there has been sporadic research devoted to using $\mathrm{VO}$ as an alternate fuel for diesel engines. It is worth noting, that the original diesel engine was designed to operate on vegetable oil, specifically peanut oil, rather than today's petroleum-derived diesel fuel [4]. The purpose of this research is to examine the potential, from the exhaust emissions perspective, of $\mathrm{VO}$ as a substitute for diesel fuel. 


\subsection{Objectives}

The objective of this research is to determine if VO is a suitable replacement, or as a blend, additional fuel for use in a diesel engine as a means of reducing reliance on fossil fuels, while improving local fuel security. This study will experimentally compare the soot and gaseous exhaust emissions from a diesel engine operating on a VO, in particular Jatropha oils, and a commercially available, D2 diesel fuel [4]. The emission products to be analyzed include:

- $\quad$ Total hydrocarbons (THC)

- Carbon monoxide (CO)

- $\quad$ Carbon dioxide $\left(\mathrm{CO}_{2}\right)$

- $\quad$ Oxides of nitrogen $\left(\mathrm{NO}_{\mathrm{x}}\right)$

- $\quad$ Nitric oxide (NO)

- Soot concentration

This effort also considers variations in the engine's fuel economy as a function of fuel type diesel fuel and vegetable oil.

All tests will be conducted on a 2005 GM/ Vauxhall 1.9 Liter diesel engine in the WVU Engine and Emissions Research Laboratory (EERL). Further discussion of the test engine and experimental equipment and procedures will be discussed in Chapter 3. 


\section{Literature Review}

\subsection{Introduction}

Using VO as fuel for in internal combustion engines is not a new concept. Rudolf Diesel's earliest engine design by was intended to run on vegetable oils (VO), an ideal fuel for farming [5]. Diesel's engine, presented at the 1900 World Fair, was powered by peanut oil. However, due to the wide availability of fossil fuels VO gave way to petroleum-derived fuels used today. That said, throughout history VO has been used in areas where petroleum-based fuels were scarce. For instance, remote European colonies relied heavily of fuel oils derived from their locally available sources [6].

Global petroleum shortages associated with World War II (WWII) precipitated considerable progress in the use of VO. During this period, Brazil and Argentina restricted the export of some crops in order to maintain their VO production [5]. Additionally, VO fuels were used by many countries during the war; the Japanese operated a battleship solely on soy bean derived fuel. Likewise, researchers in India investigated ten different types of VO during the course of the WWII [5].

Unfortunately, as petroleum sources rebounded in the post WWII environment research into VO fuels tapered off. Today VO-related research continues throughout several universities in the US, [5]. That said, not until the oil crisis of the 1970s did significant VO research reemerge in the US.

Currently, VO fuel is neither widely accepted nor readily available within the US. While there are a number of American companies selling retrofit systems for current diesel engines to enable their running on both diesel and VO fuels; like the systems available from POPDiesel [7]. 
Typically, VO's need for pre-heating requires another fuel for initial starting; thus, a bi-fuel operation. Typically, after engine start-up a closed-loop fuel heating circuit heats VO prior to injection [7]. This study employed the commercially available VO conversion system, and used VO supplied by the company.

\subsection{VO and Biofuels}

Current market demand is pushing for more flex-fuel engines capable of running on both regular and/or biodiesel. Biodiesel is any fuel derived from various types of biomass commonly available in nature [8]. Biofuels are divided into three types: first generation, second generation, and third generation. The classification for which biofuel goes where is based on what the biofuel is sourced from and how it is derived. Typically, first generation fuels are produced by traditional methods, such as fermentation/distillation (yielding ethanol fuels), and transesterification which produces esters (or biodiesel).

There is a considerable focus on refined biodiesel that takes advantage of a transesterification process. These fuels are more consistent at current fueling stations and can be burnt in current engines without modification. This is possible since the refined biodiesel shares very similar properties to the commercially available D2 diesel fuels already in use, see Table 1. However, even though a consistency between traditional diesel and biodiesel is retained, the cost related to the production of biodiesel makes a complete switch to plant-based fuels economically difficult. 
Table 1: Diesel fuel vs. Biodiesel [8]

\begin{tabular}{|l|l|l|}
\hline & D2 & B20 \\
\hline Cetane Number & 43.3 & 46 \\
\hline Specific Gravity & 0.856 & 0.862 \\
\hline Flashpoint ( C) & 62 & 90 \\
\hline Viscosity (cSt) & 2.8 & 2.92 \\
\hline Sulphur (wt\%) & 0.0476 & 0.037 \\
\hline Carbon (wt\%) & 86.9 & 85.1 \\
\hline Hydrogen (wt\%) & 13.1 & 12.6 \\
\hline Oxygen (wt\%) & $\mathrm{n} / \mathrm{a}$ & 2.1 \\
\hline Aromatics (wt\%) & 39.1 & $\mathrm{n} / \mathrm{a}$ \\
\hline Olefins (wt\%) & 1.7 & $\mathrm{n} / \mathrm{a}$ \\
\hline Saturates (wt\%) & 59.2 & $\mathrm{n} / \mathrm{a}$ \\
\hline Heat of Comb. & --- & --- \\
\hline Gross (MJ/kg) & 45.3 & 44 \\
\hline \multicolumn{1}{|c|}{ Net (MJ/kg) } & 44 & 41.4 \\
\hline Sulfated Ash & 0.001 & $<0.001$ \\
\hline Carbon Residue & 0 & 0 \\
\hline Cloud Point ( C) & -17 & -14 \\
\hline Pour Point ( C) & -21 & -15 \\
\hline Acid Number & $<0.005$ & 0.05 \\
\hline $\begin{array}{l}\text { Water and } \\
\text { Sediment }\end{array}$ & $<0.05$ & $<0.02$ \\
\hline $\begin{array}{l}\text { Copper Strip } \\
\text { Corrosion }\end{array}$ & $1 \mathrm{~A}$ & $1 \mathrm{~A}$ \\
\hline $\begin{array}{l}\text { Total Glycerine } \\
\text { (wt\%) }\end{array}$ & $\mathrm{n} / \mathrm{a}$ & 0.04 \\
\hline $\begin{array}{l}\text { Free Glycerine } \\
\text { (wt\%) }\end{array}$ & $\mathrm{n} / \mathrm{a}$ & $<0.01$ \\
\hline
\end{tabular}

From the definition of biofuels it is imperative to point out that biofuels are derived from biological (bio) material, such as soy beans, flex seed, corn, and wheat; whereas the VO fuel in this study has not been refined in anyway other than basic filtration.

However, since the engine would be operating on pure unrefined vegetable oil (VO) certain modifications would have to be made to ensure consistent operation and engine longevity. The primary issue regarding the use of $\mathrm{VO}$ as a fuel is its significantly higher 
kinematic viscosity when compared with D2. Table 2 shows the various fuel properties of VO. The significantly higher kinematic viscosity of Jatropha oil, the VO employed in this study is a major design factor when considering an engine design for $\mathrm{VO}$ operation.

Table 2: Fuel property of Jatropha oil (VO)

\begin{tabular}{|l|l|}
\hline Property & Jatropha Oil (VO) \\
\hline Density $\left(\mathbf{k g} / \mathbf{m}^{\mathbf{3}}\right)$ & 921.8 \\
\hline $\begin{array}{l}\text { Kinematic Viscosity @ } \\
\text { 40 C }\end{array}$ & 34.33 \\
\hline Flash Point ( C) & 180 \\
\hline Carbon Residue \% (w/w) & 0.74 \\
\hline Ash Content \% (w/w) & 0.036 \\
\hline Carbon \% (w/w) & 76.56 \\
\hline Hydrogen \% (w/w) & 13.19 \\
\hline Nitrogen \% (w/w) & 0.34 \\
\hline Copper Corrosion & --- \\
\hline
\end{tabular}

Preheating is one means to address the issue of high kinematic viscosity. Preheating reduces the VO viscosity before being supplied to the engine's injector system. In current designs, vehicles operate both VO fuel and pump diesel, functioning as a dual-fuel vehicle [9]. In such a design the engine starts on pump diesel while VO fuel is heated, and when the desired temperature is attained the switch is made to VO. Likewise, before the engine is shut down the fuel is again switched to diesel to purge the fuel lines and the engine of any VO that may accumulate during non-operating periods. 


\subsection{Current VO Systems}

As previously mentioned VO fuel is significantly different than pump diesel, or biodiesels. In particular, the kinematic viscosities of the two types of fuels are significantly different; approximately 12 times greater for VO.

Current practice suggests that VO should be heated to approximately $160 \mathrm{~F}(\sim 70 \mathrm{C})$. Techniques for preheating the VO fuel include using electric heaters or fuel heat exchangers that take advantage excess heat within the engine's cooling system. There are several commercially available systems which use a combination of heating methods to achieve a low viscous, smoothly flowing fuel. Operationally, once the appropriate temperature range is achieved a solenoid valve near the fuel injector pump is switched from pump diesel to VO fuel. From this point the engine can be safely operated on VO, so long as proper fuel temperature $(113-131$ deg F) can be maintained [10]. However, most system designs require, or suggest, some sort of engine shut down procedure to reduce any VO deposits in the fuel injectors or engine. This typically requires the engine to be switched back to pump diesel for a short time before shut down; thus, purging the fuel system of any residual VO fuel. These additional engine components required for this type of dual fuel systems is complicated; Figure 1, illustrates a typical diesel/ VO dual fuel system for a Ford Powerstroke engine. From this figure it is possible to how an entirely new fuel system has to be added to the current system in order to achieve a functioning dual fuel system. Additionally, the figure shows that the VO fuel system requires additional filters and coolant plumping in order to get the fuel clean and viscous enough to function properly in the conventional diesel engine. 


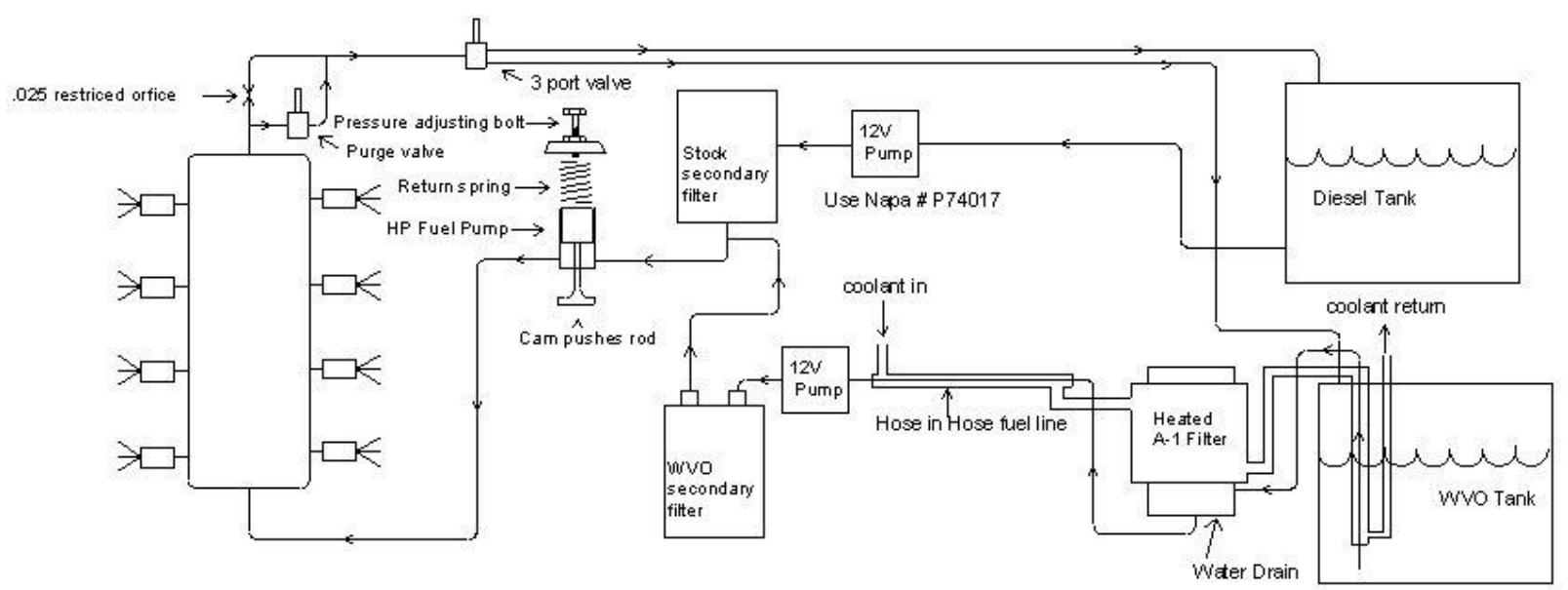

Figure 1: Two tank on demand VO system for Ford Powerstroke[9]

Also, most VO systems in use today rely on a two tank fuel system to reduce the chance of contamination between the two fuels. Additionally, separate fuel returns have to be installed so the proper fuel is returned to the correct tank.

Finally, since a VO fuel system requires some discretion as to when switching between fuels is appropriate, most systems require the operator to manually switch fuels (by electric relay switch). The future of these systems, will computer controlled modules make operation of VO fueled vehicles user friendly and as simple as operating any other diesel powered vehicle on the road today.

\subsection{Comparison of Different VO as Fuels}

VO is a generalized term to describe the oil produced by any oilseed bearing crop. Therefore, there is a variety in types of VO, including oils such as soy bean, palm jatropha oil, peanut rapeseed, just to name a few. As it can be imagined each of these different oils has a different chemical makeup, slightly affecting the performance of each. Nettles-Anderson and 
Olsen (2009), show that the differences in cultivation and growing conditions can even affect the production of oil within the same plant species [4].

Nettles-Anderson and Olsen, (2009) reviewed several VO sources and assessed the characteristics of how each oil composition affects diesel engine operation. Table 3 shows the seven key characteristics to studying prospective VO fuels.

Table 3: Impact of VO on engine performance and durability [4]

\begin{tabular}{|c|c|c|c|}
\hline Oil Properties & $\begin{array}{c}\text { Engine } \\
\text { Efficiency }\end{array}$ & Emissions & $\begin{array}{c}\text { Engine } \\
\text { Durability }\end{array}$ \\
\hline High Viscosity & $\begin{array}{l}\text { Results in } \\
\text { poor } \\
\text { efficiency }\end{array}$ & $\begin{array}{l}\text { Adversely } \\
\text { affects } \\
\text { emissions }\end{array}$ & $\begin{array}{l}\text { Limits engine } \\
\text { Life }\end{array}$ \\
\hline Cloud point & $\begin{array}{l}\text { Lower cloud } \\
\text { point } \\
\text { corresponds } \\
\text { to lower } \\
\text { viscosity }\end{array}$ & Unknown & $\begin{array}{l}\text { High cloud } \\
\text { Point cloud } \\
\text { limit engine } \\
\text { life }\end{array}$ \\
\hline $\begin{array}{c}\text { Lower Heating Value } \\
\text { (LHV) }\end{array}$ & $\begin{array}{l}\text { Low LHV } \\
\text { results in } \\
\text { higher fuel } \\
\text { consumption }\end{array}$ & $\begin{array}{l}\text { Increases } \\
\text { emissions }\end{array}$ & Unknown \\
\hline Phosphates & $\begin{array}{c}\text { High levels } \\
\text { decrease } \\
\text { power } \\
\text { output } \\
\end{array}$ & Unknown & $\begin{array}{l}\text { Limits filter } \\
\text { life }\end{array}$ \\
\hline High Density & $\begin{array}{l}\text { More energy } \\
\text { per volume } \\
\text { decreases } \\
\text { fuel } \\
\text { consumption }\end{array}$ & $\begin{array}{c}\text { Decreases } \\
\text { emissions to } \\
\text { a point }\end{array}$ & Unknown \\
\hline $\begin{array}{l}\text { Elevated Fuel } \\
\text { Temperature }\end{array}$ & $\begin{array}{l}\text { Greater than } \\
90 \mathrm{C} \text { may } \\
\text { cause } \\
\text { component } \\
\text { damage }\end{array}$ & $\begin{array}{l}\text { Could } \\
\text { increase } \mathrm{NO}_{\mathrm{x}}\end{array}$ & $\begin{array}{l}\text { Increases } \\
\text { engine life due } \\
\text { to viscosity } \\
\text { decrease }\end{array}$ \\
\hline $\begin{array}{c}\text { Polyunsaturated Fatty } \\
\text { Acids }\end{array}$ & $\begin{array}{l}\text { Low levels } \\
\text { do not affect } \\
\text { performance }\end{array}$ & $\begin{array}{l}\text { Higher levels } \\
\text { increase } \mathrm{NO}_{\mathrm{x}}\end{array}$ & $\begin{array}{c}\text { Adversely } \\
\text { affects engine }\end{array}$ \\
\hline
\end{tabular}

Their efforts show that high viscosity oils are poor choices for use in a diesel engine. Previous researchers [4] have discovered that this often leads to poor engine efficiency and 
untimely reduces the operational life of an engine. Nettles-Anderson and Olsen (2009) identify additional imporatant VO characteristics, in particular the impact of polyunsaturaed fatty acids present in the oil. Their findings support many research [4] efforts that find high levels of polyunsaturated oils often lead to greater carbon deposit build up in both fuel injectors and egine cyclinders. VO that are made up of monounsaturated fatty acids, which tend to have better viscous and cloud point properties. Examples of these types of VO oilseeds are: safflower, soybean, coconut, jatropha, rapeseed and palm.

However, even though there are lists of VO properties ideal for use in diesel engine, the crop production capibilities and economical feasibility of the different oils also plays a key role in the choice of VO. An appealing aspect of VO fuels is that they can be produced (in some cases recycled), refined, and sold in local areas ultimately reducing cost by reduing the time and distance to market. This means that different oils will be used in different regions based on the oilseed crops that are locally available.

\subsection{Emission Trends with VO Operation}

In recent years the emission standards both in the United States and Europe have become more stringent. For this reason it is important to consider potential engine exhaust emissions when analyzing an alternative fuel source, like VO. There has been significant research in the field of VO fuel emissions [6]. Typically, VO fuels reduce the production of $\mathrm{NO}_{\mathrm{x}}$ emissions; for example, Neetles-Anderson and Olsen (2009) reported 25\% reductions when seed-oil fuels as

compared to diesel fuel [4]. Vojtisek-Lom (2007) tested a fleet of VO fueled vehicles, and reported a noticeably lower $\mathrm{NO}_{\mathrm{x}}$ when compared to the same vehicles being operated on diesel fuel alone [10]. However, VO fuel engines reportedly produce both higher THC and CO 
emissions. $\mathrm{CO}_{2}$ is also reported to be higher for the $\mathrm{VO}$ fuels. Of course, the soot and particulate matter (PM) emissions remain a point of extensive debate. At this point, it is important to clarify that the POPDiesel project did not gravimetrically measure PM emissions; rather this study focused specifically on the soot emissions, measured with an AVL Soot Sensor. Because these emissions are visibly noticeable there may be common misconceptions, however, NettlesAnderson \& Olsen (2009) found a significant reduction, 30\% to 50\%, in particulate matter through their tests done at Colorado State University [4]. Table 4 shows the total emissions recorded by a study of VO fuels operating in a variety of driving conditions over a $\sim 21 \mathrm{~km}$ route.

Table 4: VW \#1 vs. VW \#2 VO Fuel to Diesel Fuel [10]

Summary of test data for VW \#1

\begin{tabular}{|c|c|c|c|c|c|c|c|c|c|c|}
\hline Total $20.9 \mathrm{~km}$ route $(\mathrm{g} / \mathrm{km})$ & $\mathbf{N O}_{\mathbf{x}}$ & $\mathbf{H C}$ & $\mathrm{CO}$ & $\mathrm{CO}_{2}$ & $\mathbf{P M}$ & $\mathbf{N O}_{\mathbf{x}}$ & HC & $\mathrm{CO}$ & $\mathrm{CO}_{2}$ & PM \\
\hline Diesel Fuel & 0.57 & 0.15 & 0.63 & 133 & 0.035 & 0.7 & 0.08 & 0.05 & 136 & 0.03 \\
\hline Vegetable Oil & 0.53 & 0.19 & 0.77 & 139 & 0.045 & 0.59 & 0.1 & 0.07 & 133 & 0.035 \\
\hline Vegetable oil vs. diesel & $-8 \%$ & $28 \%$ & $21 \%$ & $4 \%$ & $29 \%$ & $-15 \%$ & $29 \%$ & $41 \%$ & $-2 \%$ & $18 \%$ \\
\hline Diesel oxidation catalyst effect & $\mathbf{N O}_{\mathbf{x}}$ & HC & $\mathbf{C O}$ & & $\mathbf{P M}$ & & & & & \\
\hline Diesel Fuel & $21 \%$ & $-48 \%$ & $-92 \%$ & & $-14 \%$ & & & & & \\
\hline Vegetable Oil & $22 \%$ & $-47 \%$ & $-91 \%$ & & $-22 \%$ & & & & & \\
\hline \multicolumn{11}{|l|}{ Summary of test data for VW \#2 } \\
\hline Total $20.9 \mathrm{~km}$ route $(\mathrm{g} / \mathrm{km})$ & $\mathbf{N O}_{\mathbf{x}}$ & $\mathbf{H C}$ & $\mathrm{CO}$ & $\mathrm{CO}_{2}$ & $\mathbf{P M}$ & $\mathbf{N O}_{\mathbf{x}}$ & HC & $\mathrm{CO}$ & $\mathrm{CO}_{2}$ & PM \\
\hline Diesel Fuel & 0.89 & 0.09 & 0.43 & 102 & 0.027 & 0.9 & 0.08 & 0.06 & 97 & 0.021 \\
\hline Vegetable Oil & 0.72 & 0.13 & 0.7 & 107 & 0.031 & 0.79 & 0.09 & 0.03 & 98 & 0.023 \\
\hline Vegetable oil vs. diesel & $-20 \%$ & $34 \%$ & $60 \%$ & $5 \%$ & $14 \%$ & $-13 \%$ & $14 \%$ & $-43 \%$ & $2 \%$ & $8 \%$ \\
\hline Diesel oxidation catalyst effect & $\mathbf{N O}_{\mathbf{x}}$ & $\mathbf{H C}$ & $\mathrm{CO}$ & & $\mathbf{P M}$ & & & & & \\
\hline Diesel Fuel & $1 \%$ & $-17 \%$ & $-87 \%$ & & $-21 \%$ & & & & & \\
\hline Vegetable Oil & $10 \%$ & $-29 \%$ & $-95 \%$ & & $-25 \%$ & & & & & \\
\hline
\end{tabular}



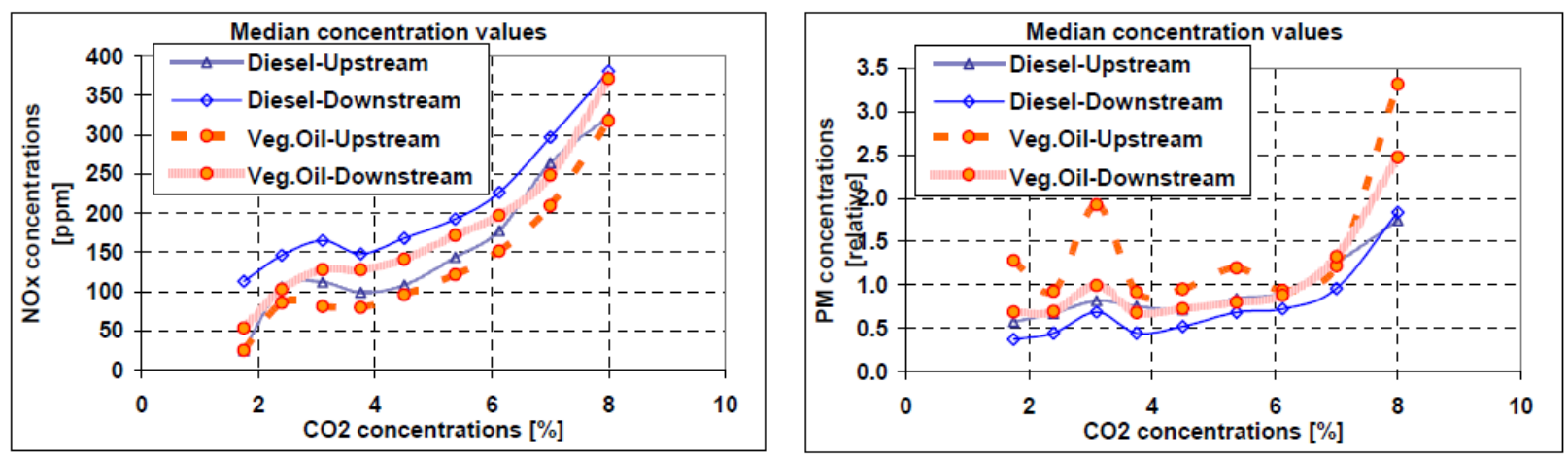

Figure 2: Correlations among $\mathrm{CO}_{2}, \mathrm{NO}_{\mathrm{x}}$ and $\mathrm{PM}[10]$

Figure 2 illustrates findings of Vojtisek-Lom (2007) suggests that when engines are operated at moderate to high loads the resulting emissions of both VO fuel and diesel are virtually the same. The most noticeable difference is at low speeds and light engine loads. At these lower speeds $\mathrm{NO}_{\mathrm{x}}$ production of an engine operating on $\mathrm{VO}$ decrease, while the resulting PM concentrations increase; when compared to the same engine operating on diesel fuel. This is likely related to the engine temperature being lower during near idle conditions. As mentioned before, the need to preheat VO suggests that a lower engine temperature may adversely affect the performance of $\mathrm{VO}$ fueled engine.

Likewise, a lower temperature of a $\mathrm{VO}$ fueled engine results in an incomplete combustion process; as a result, there is an increase of carbon deposits on surfaces of the combustion chamber and the nozzle of the fuel injectors. This adversely affects fuel injection and results in poor combustion; thereby, increasing both gaseous and soot emissions. This can be avoided by either running the engine at higher temperatures (not ideal), or by ensuring that the VO is maintained at a sufficient temperature to sustain proper injection. 


\subsection{Major Benefits of Vegetable Oil Fuels}

Vegetable oils are becoming increasingly popular as a cost effective and locally available renewable fuel [10]. Historically, these oils were the favored fuel, and have often been used in diesel engines during times of mass fuel shortages [5]. Presently, VO fueled vehicles are becoming popular as a means of reducing fuel costs. Through an internet survey for VO systems much information can be gathered including many commercial companies selling kits to modify existing diesel vehicles. With a VO vehicle modification, it appears that VO fueled vehicles, overall, have emissions consistent with current petroleum diesel fueled vehicles under medium, to heavy, loads. Additionally, most studies notice a significant reduction in $\mathrm{NO}_{\mathrm{x}}$ and $\mathrm{PM}$ production for VO fueled engines.

Furthermore, as mentioned in the introduction of the section there is a drive in the U.S., and other nations, to be more energy independent. The use of locally grown, refined and sold VO fuels could help ease the transition of this to a secure/reliable fuel and energy supply. As VO conversion efforts mature there may be reason for an economically based study/consideration, to assess the overall impact to our nation. Hypothetically, if it were possible to fuel a large portion of diesel engines via VO, the demand for production of grain, seeds or other oil producing products would increase proportionally; thus, introducing competition for the same products as a food source. It would seem reasonable that cost for such products would likewise rise; as a result, the cost savings to the customer may be neutral. However, if such fuels could be derived from bio-mass components, the overall savings to consumer could be reduced. 


\section{Experimental Setup}

\subsection{Test Engine}

This study employed a 1.9 liter GM/Vauxhall diesel engine; (from a 2005 Vauxhall Vectra) operating on $100 \%$ VO. Table 5 outlines the test engine's specifications.

Table 5: 1.9L Test Engine Specifications

\begin{tabular}{|c|c|}
\hline Engine Manufacturer & GM/Vauxhall \\
\hline Engine Model & M737 "Epsilon" GDX 8V \\
\hline Engine Code & LK5Z19DT \\
\hline Engine Model Year & 2005 \\
\hline Power Rating & $119 \mathrm{hp} \mathrm{(88.74} \mathrm{kW)@} \mathrm{4000} \mathrm{rpm}$ \\
\hline Combustion Cycle & 4-stroke \\
\hline Combustion System & Direct Injection, High Pressure Common \\
& Rail \\
\hline Configuration & Inline 4 cylinder \\
\hline Displacement & cubic in. (1.9 L) \\
\hline
\end{tabular}

This test engine has been used in various studies at WVU's Center for Alternative Fuels, Engines and Emissions labs (CAFEE) [11]. The following engine performance curve was generated in one of those efforts; Figure 3 shows a plot of engine torque and power versus engine speed. 


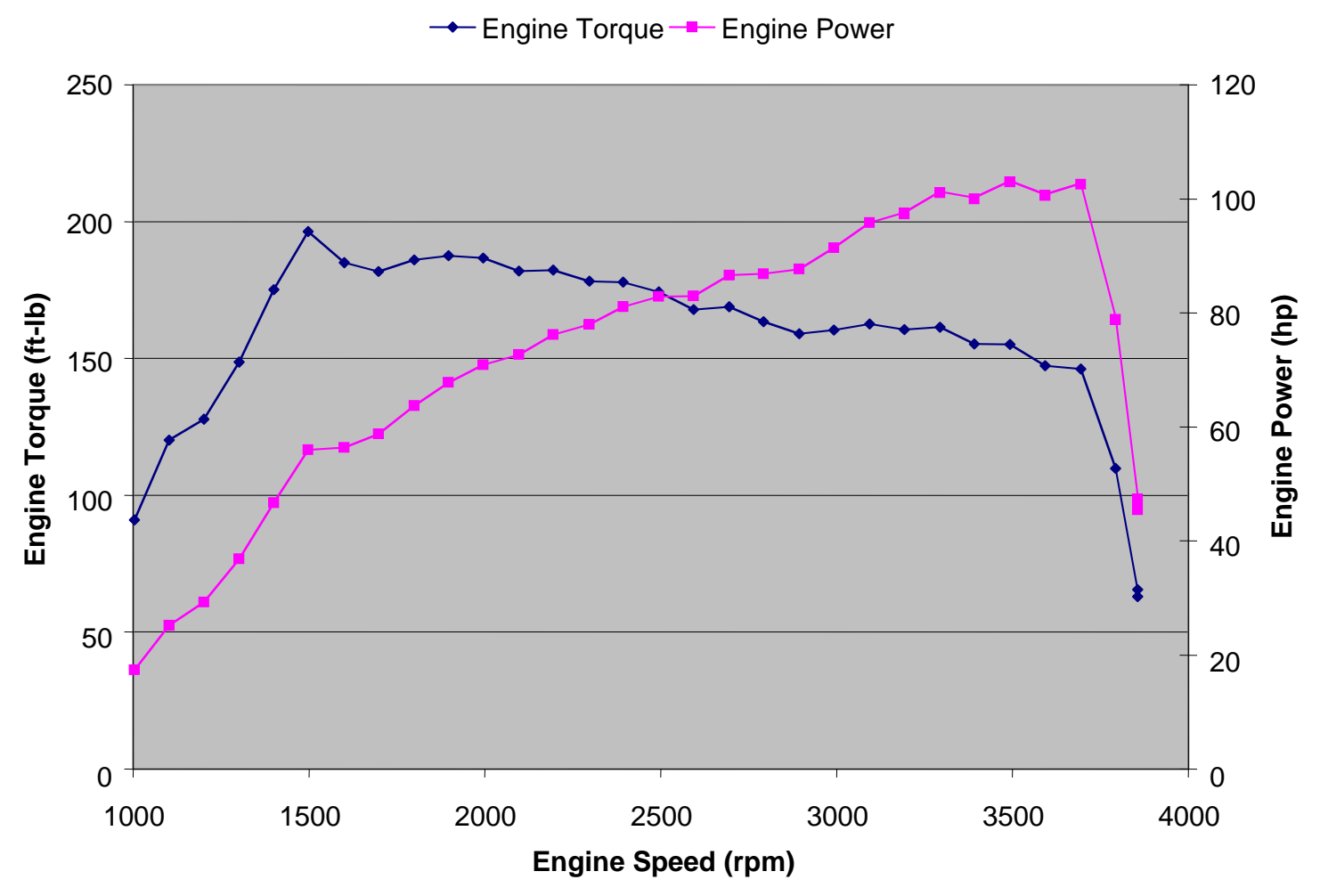

Figure 3: Engine Torque and Power Curves vs. Engine Speed

\subsection{VO Fuel System}

The VO fuel system is an auxiliary fuel system such those previously addressed in Chapter 2. The company, that produced the unit used in this study, claims that this system was specially designed to be user friendly and reliable for use on a variety of both on-road and offroad diesel engine applications [7]. This is done by using an on-board computer monitoring system that manages engine and fuel operation; this assures that the $\mathrm{VO}$ fuel is only introduced at the proper fuel and engine temperatures. Additionally, this system has a patented process for attaining high $\mathrm{VO}$ fuel temperature in a much shorter time frame allowing for "greater fuel savings, and cleaner emissions [7]." Finally, the manufacture suggests that the system should be used in conjunction with their refined waster VO fuel, which contains some additives, but does mention that the system can run on any filtered VO fuel. 
The VO system is a self contained unit (other than the parts installed under the hood) that monitors both engine and fuel temperature, while pumping VO fuel to the engine. Figure 4 shows a typical installation in a 2006 Ford F-250 pickup truck.

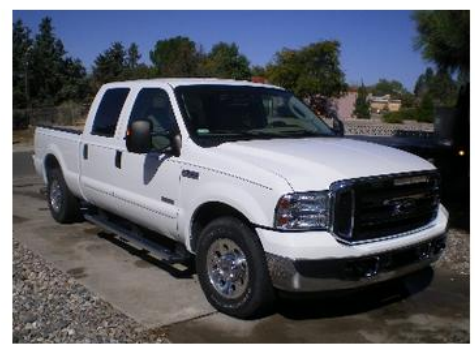

2006 Ford F-250 6.0L Powerstroke

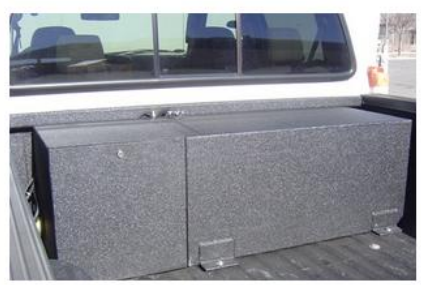

POP Box locked up

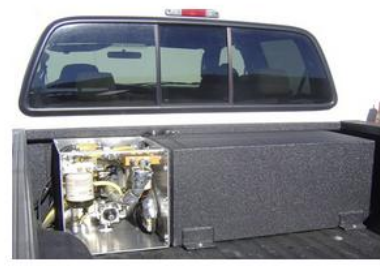

POP Box open for fuel fill or filter change

Figure 4: VO Fuel System Installed [7]

For this study the engine will not be initially started on diesel fuel, as the typical dual fuel configuration, but only on VO fuel to ensure there is no contamination of fuels during testing.

\subsection{Test Cycle}

The test engine was operated over a test matrix of six modes of varying engine speeds and load, for both petroleum diesel and VO fuel. These tests were conducted in the EERL and were done using an Eaton $225 \mathrm{HP}$ alternating current (AC) engine dynamometer. All emissions tests employed the full-flow constant volume sampling (CVS) dilution tunnel and met the requirements outlined in Title 40 Part 1065 of the Code of Federal Regulations (or CFR). Gaseous emissions samples for these engine tests were collected using the CVS system and 
analyzed using a Horiba Mexa 7200-D gaseous sampling bench. Soot concentration samples were drawn from the raw exhaust stream during each test and measured using an AVL 483 Micro Soot Sensor. A more detailed description of the aforementioned test components is provided in the laboratory setup section of this thesis. The following table lists the six test modes that were conducted on the engine for comparing both petroleum diesel and VO fuel.

Table 6: VO Fuel Study Test Matrix

\begin{tabular}{|c|c|c|}
\hline \multicolumn{3}{|c|}{ GM/ Vauxhall 1.9L } \\
\hline Mode & Engine Speed & Engine Torque \\
\hline 1 & $1800 \mathrm{rpm}$ & $100 \%$ load \\
\hline 2 & $1800 \mathrm{rpm}$ & $25 \%$ load \\
\hline 3 & $1800 \mathrm{rpm}$ & $50 \%$ load \\
\hline 4 & $2400 \mathrm{rpm}$ & $100 \%$ load \\
\hline 5 & $2400 \mathrm{rpm}$ & $25 \%$ load \\
\hline 6 & $2400 \mathrm{rpm}$ & $50 \%$ load \\
\hline
\end{tabular}

\subsection{Laboratory Testing Setup}

\subsubsection{Engine Controller}

A Drivven 1.9L Open Engine Controller System was used to control the GM/ Vauxhall engine. The Drivvven System was necessary since an engine control unit (ECU) was not available to operate the engine. This system is primarily comprised of National Instruments (NI) hardware and makes use of the LabView control software. The system allows researchers' the ability to finely tune the test engines operation through a well organized graphical user interface. Table 7 outlines both the NI and Drivven hardware used in this control system. 
Table 7: 1.9L Opel Drivven Control System

\begin{tabular}{|l|c|}
\hline \multicolumn{1}{|c|}{ Hardware Description } & Quantity \\
\hline National Instruments Hardware & \\
\hline PXI-1042 PXI Chassis & 1 \\
\hline PXI-8106 RT Controller & 1 \\
\hline PXI-7813R FPGA Card & 1 \\
\hline cRIO-9151 R-Series Expansion Chassis & 2 \\
\hline SH68-C68-S (2m) R-Series Cable & 2 \\
\hline cRIO-9411 6-Channel Digital Input Module & 1 \\
\hline cRIO-9401 8-Channel TTL Digital I/O Module & 1 \\
\hline Drivven Hardware & \\
\hline AD Combo Module Kit & 1 \\
\hline PFI Injector Driver Module Kit & 1 \\
\hline Low-Side Driver Module Kit & 1 \\
\hline Direct Injector Driver Module Kit & 2 \\
\hline $\mathrm{O}_{2}$ Sensor Module Kit & 1 \\
\hline ECU breakout connection & 1 \\
\hline
\end{tabular}

Hard Wired Connection to Control System

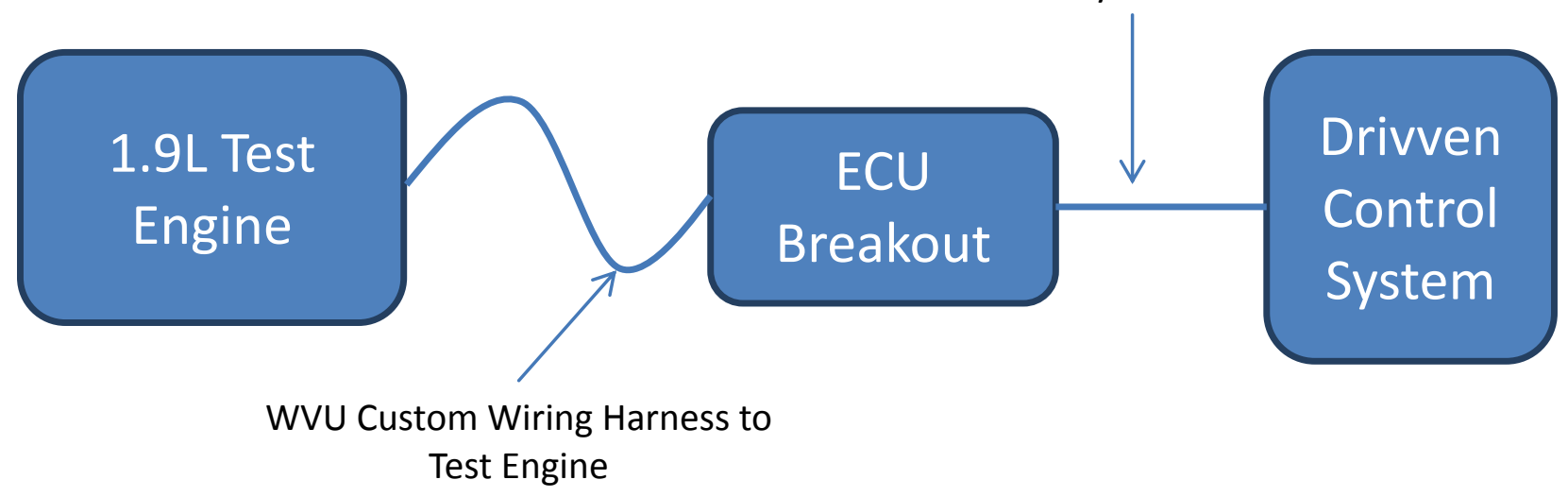

Figure 5: Engine Control System Diagram

Figure 5 is a block diagram illustrating the major components of the engine control system. First is the test engine, which was discussed in the previous section. Connected to the engine is a custom wiring harness that had been fabricated in-house at WVU for previous research efforts 
[11]. The wiring harness is connected to the ECU Breakout Connection unit, Figure 6, which provides the necessary interface between the wired connections and the Drivven Control System.

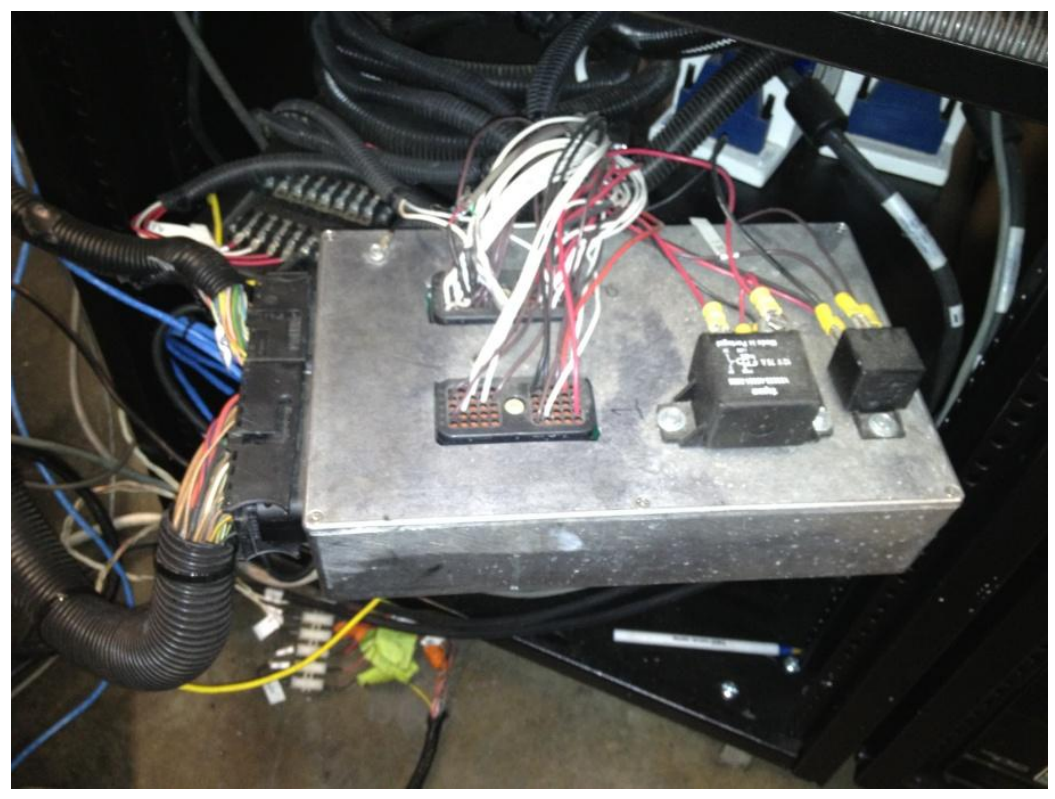

Figure 6: ECU Breakout Connection Module

The output side of this module connects directly to the Drivven Modules, as outlined in Table 7.

Figure 7 shows the control system used as interface for adjusting the engine's operation.

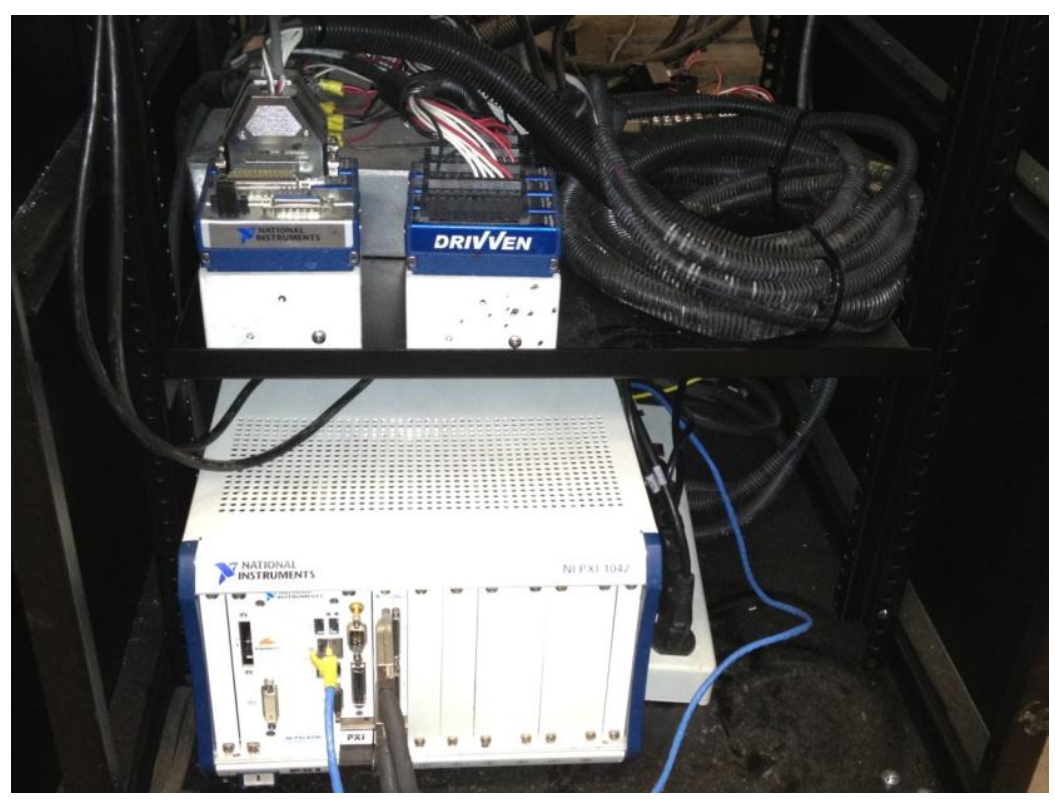

Figure 7: NI and Drivven Control System 
All the above mentioned components together provide an effective means to maintain a specified engine speed while the desired performance parameters (test matrix data) can be monitored and accurately collected during the various test modes for both baseline and experimental fuel tests.

\subsubsection{Fuel Metering}

Accurately monitoring of fuel flow rate during an engine test is critical. The Omega FTB1311 flow meter was selected for its good wear resistant design turbine type meter; the ware resistant attribute helps maintain the flow meter's calibration over extended periods of time. The meter relies on magnetic pickup that generates an electronic pulse proportional to the turbine's speed, that can be associated (calibrated) to reflect the total volume fuel that passes through the meter [12].

\subsubsection{AC Dynamometer}

An Eaton 225 HP AC dynamometer was used for this testing. The engine dynamometer is connected via a shaft and Vulcan connector to the flywheel of the engine being tested. The opposite end of dynamometer's shaft is connected to an alternating current electric generator. Thus, by running the test engine the rotor of the generator is turned (provided mechanical power), resulting in the creation of an electric current. This current is proportional to the power output from the test engine. Consequently, a load can be applied to a motoring engine by increasing the rotational resistance within the magnetic field of the generator through the introduction of electric current to the electric generator.

Engine torque is determined by using a torque arm. This is a structure arm externally connected to the electric generator housing, and is linked to a load cell (force indicator) that is 
anchored to the floor, or other stationary support. It assesses torque by measuring the force being applied to the load cell at some distance (equal to the length of the torque arm).

$$
\text { Torque }(\boldsymbol{\tau})=\text { Force }(\mathbf{F}) * \text { Distance }(\mathbf{d})
$$

Equation 1

Output power is simply determined by multiplying the measured engine torque by the rotational speed. The rotational speed is measured by the dynamometer through a rotational encoder (speed device). Because the engine is directly linked to the dynamometer it is reasonable to assume negligible loss between the engine and dynamometer; thus, the power assessed using dynamometer's measured torque and speed can be directly attributed to the engine's performance. The engine power in English units (hp) is calculated as follows:

$$
\mathbf{P}_{\mathrm{hp}}=\frac{\tau_{\mathrm{lb} \times \mathrm{ft}} * \omega_{\mathrm{rpm}}}{5252}
$$

Equation 2

Figure illustrates components of a dynamometer, and the testing setup is illustrated in Figure . This laboratory diagram depicts the test engine's attachment to the AC dynamometer. It is important to mention that the dynamometer must be calibrated in order to provide reliable data. This is done by applying a series of known weights to the torque arm, and calibrating these known forces to the analog output of the load cell. 


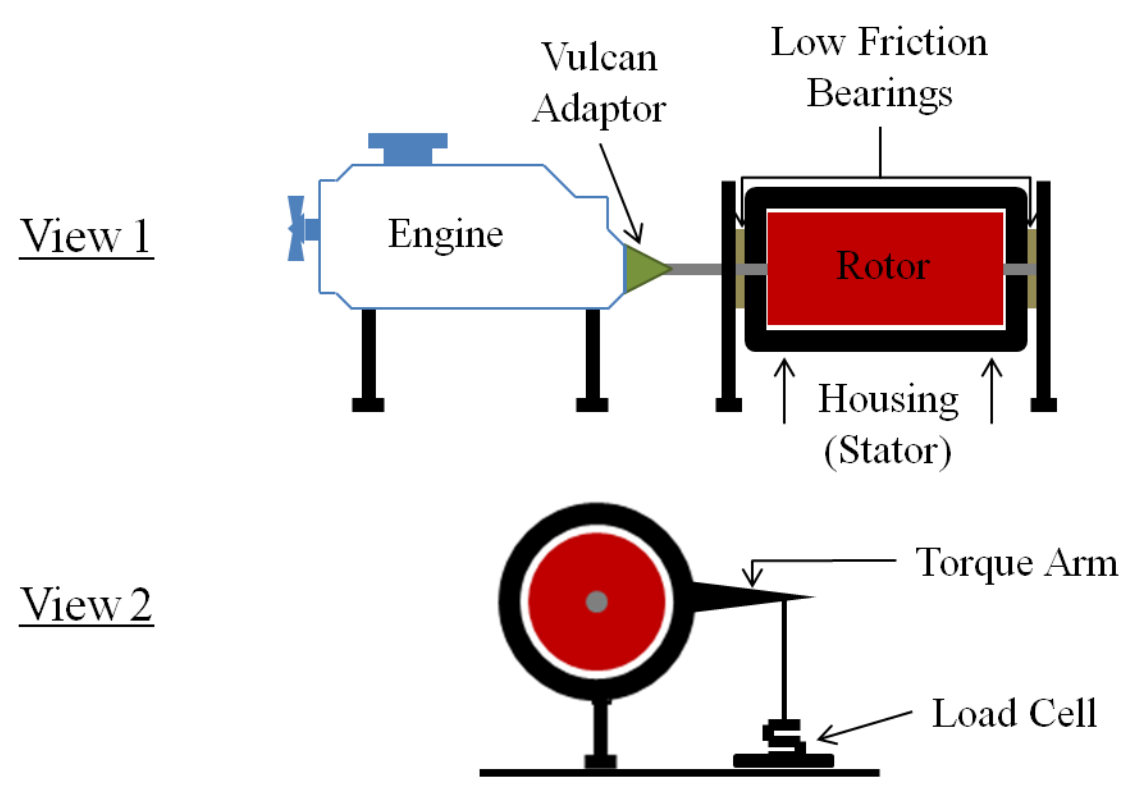

Figure 8: Components of a Dynamometer

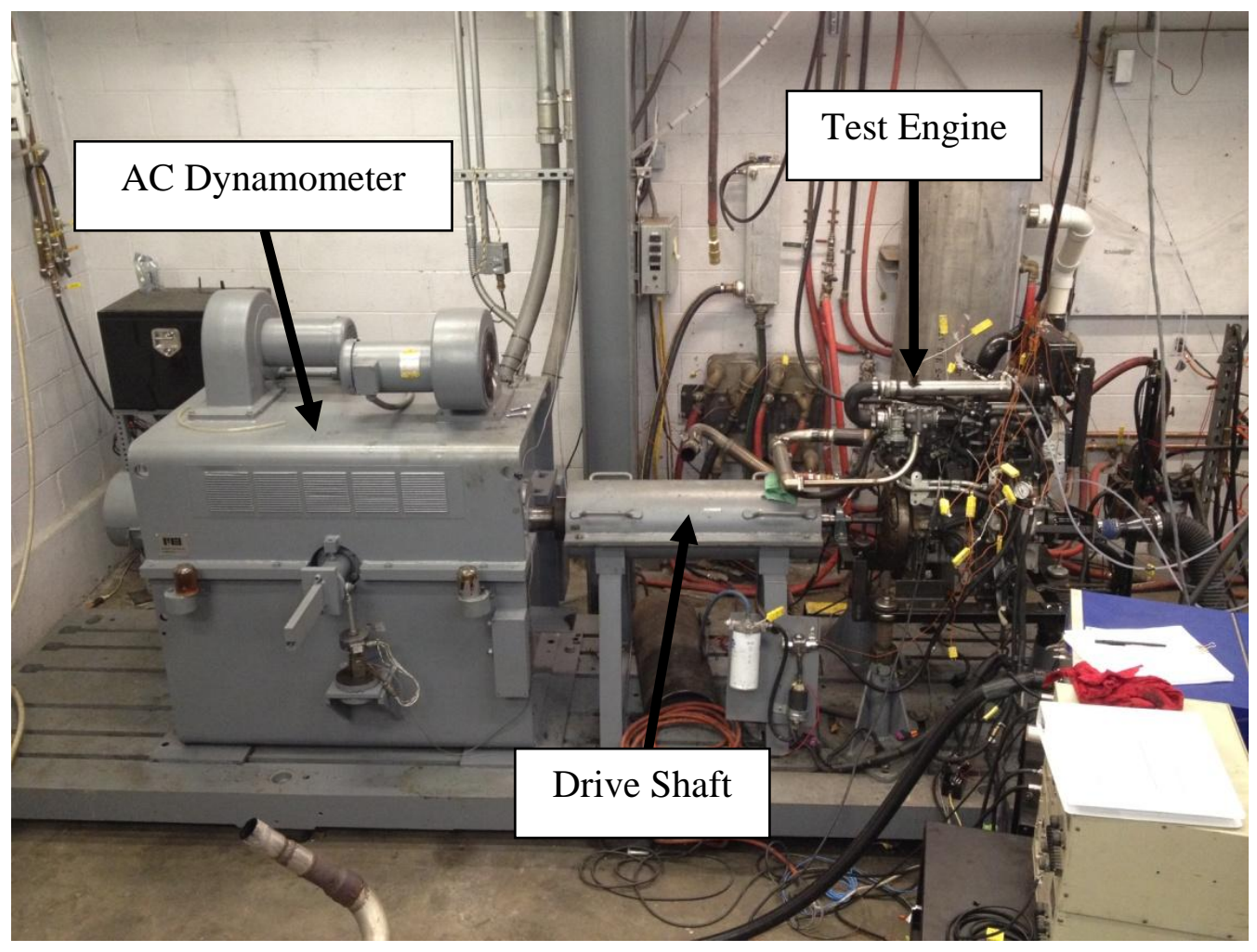

Figure 9: Example of a Test Engine Setup on Eaton 225 HP AC Engine Dynamometer 
Furthermore, it is important to mention that the calibration weights used in the EERL have traceable NIST verifications on-record to ensure accurate and reliable measurements. Also, the dynamometer is controlled using a Dyn-loc control System.

\subsubsection{Dilution Tunnel}

The engine exhaust was directly routed to the constant volume sampling (CVS) dilution system. The exhaust dilution and emissions measurement system used in this study was designed in-house at WVU in accordance with the Code of Federal Regulation Title 40 Part 1065.

Dilution tunnels mix dilution air that is provided via the in-house HVAC system with the raw exhaust being emitted from the test engine and maintains a constant mass flow rate. The dilution process provides a consistency for emissions testing so that the resulting test samples can be compared with samples taken at different times, or even different engines. A sub-sonic venturi is used to meter the diluted exhaust. To prevent post emission chemical reactions or vapor condensation, the resulting exhaust sample is passed to the gaseous emissions sampling system via a heated hose.

Calibration of the tunnel is done through CVS batch sample verification, otherwise known as propane injection. The procedure injects a known mass of propane into the system using a propane injection kit. Meanwhile the $\mathrm{HC}$ analyzer monitors and measures the propane concentration in the tunnel. For the tunnel to be successfully calibrated it must record measurements within $2 \%$ of the propane concentration injected. Additionally, this measurement must be repeated three consecutive times with a tolerance of $1 \%$ difference between injection runs. The federal code outlining the construction of these tunnels is very specific to assure that data collected via various test systems can be directly compared. 


\subsubsection{Gaseous Emissions Sampling System}

A HORIBA Mexa 7200-D was used to analyze the gaseous emissions during these engine tests. The measured gaseous pollutants included: $\mathrm{CO}_{2}, \mathrm{CO}, \mathrm{THC}$, and $\mathrm{NO}_{\mathrm{x}}$. The Mexa 7200-D is a continuous sampling unit that accepts a sample flow rate of 12 liter per minute, and draws heated samples from the CVS dilution tunnel. It is a completely automated unit, which requires little user input during testing. However, it is important to recognize that a single exhaust flow sample represents that moment in time; therefore, it is important to assure the system is running at a steady state.

The HORIBA Mexa 7200-D system uses a series of five different analyzers of four types to detect the concentrations of each of the five chemical species being analyzed. The emissions measured exhaust system includes: two NDIR sensors, an FID sensor, a GC-FID, and one CLD. Table 8 shows the list of analyzers used; the pollutant measured, measurement principal, measurement ranges and model numbers.

Table 8: MEXA-7200D Analyzers and Ranges [13]

\begin{tabular}{|l|l|l|l|}
\hline Gas & Type & Ranges & Model \\
\hline CO & NDIR & $0-10-200 \mathrm{ppm}$ & AIA-721SLE \\
\hline CO $_{\mathbf{2}}$ & NDIR & $0-0.5-20 \mathrm{vol} \%$ & AIA-722 \\
\hline THC & FID & $0-1-50 \mathrm{ppmC}$ & FIA-726SLE \\
\hline CH $_{\mathbf{4}}$ & GC-FID & $0-1-50 \mathrm{ppmC}$ & GFA-720SLE \\
\hline NO $_{\mathbf{x}}$ & CLD & $0-1-50 \mathrm{ppmC}$ & CLA-750SLE \\
\hline
\end{tabular}

\section{Non-Dispersive Infrared Analyzer (NDIR)}

The Mexa system uses two as non-dispersive infrared analyzers, to measure the concentrations of both $\mathrm{CO}$ and $\mathrm{CO}_{2}$ present in the exhaust sample. A non-dispersive infrared 
analyzer is a type of spectrophotometer that measures molecular light absorption by using a set of filters tuned to identify light intensity over small a range of wavelengths [14].

Figure 1 illustrates the basic function of a NDIA analyzer. Infrared light emitted from a light source is split into two beams via a chopper lens. Each light path proceeds through a separate volume of gas: one is the exhaust sample, and the other reference gas, e.g., nitrogen or argon. Each of the two gases then absorbs an amount of light relative to its concentration (the reference sample is considered constant). The transmittance ratio (Tr) in terms of a voltage is measured for both the sample and reference gas. The signals are amplified and electronically compared and captured via a data logging system [14].

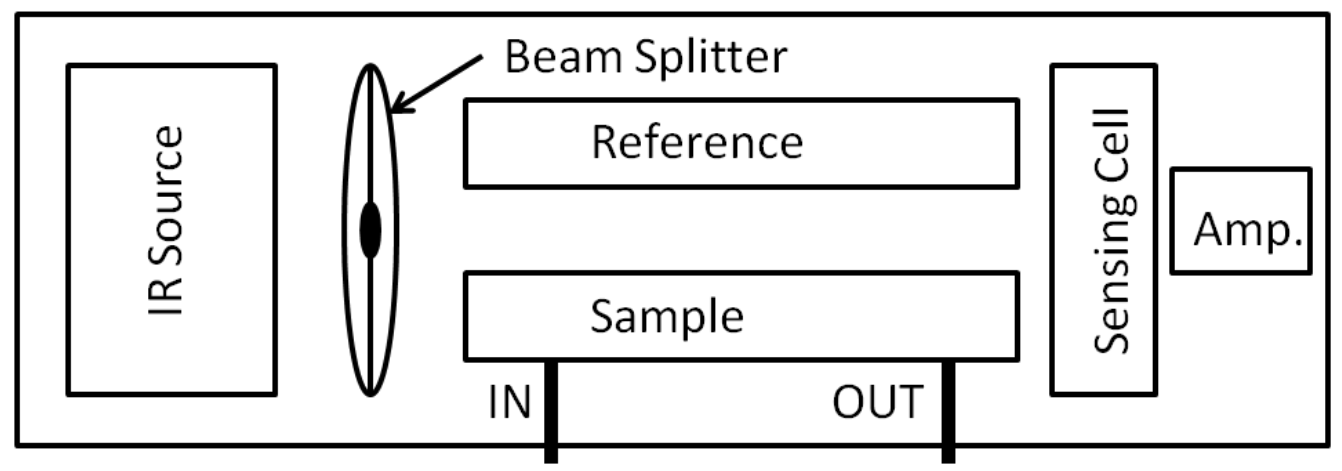

Figure 10: NDIA Type Analyzer [15]

Although the Mexa system is self calibrating, care must be taken to assure that water does not introduce interference. This occurs because water vapor and $\mathrm{CO}_{2}$ share similar infrared bandwidths. Thus, water interference checks are conducted for these systems.

\section{Flame Ionization Detector}

To measure the concentration of THC a FID was used. A flame ionization detector works by mixing a collected sample with hydrogen gas and then burning the mixture at a relatively high temperature (approximately $2100^{\circ} \mathrm{C}$ ). This combustion process frees ions and 
electrons from the organic molecules and allows them to interact with an electrometer. The resulting change in current is related to the concentration of organic compounds (or THC) present in the exhaust sample [14].

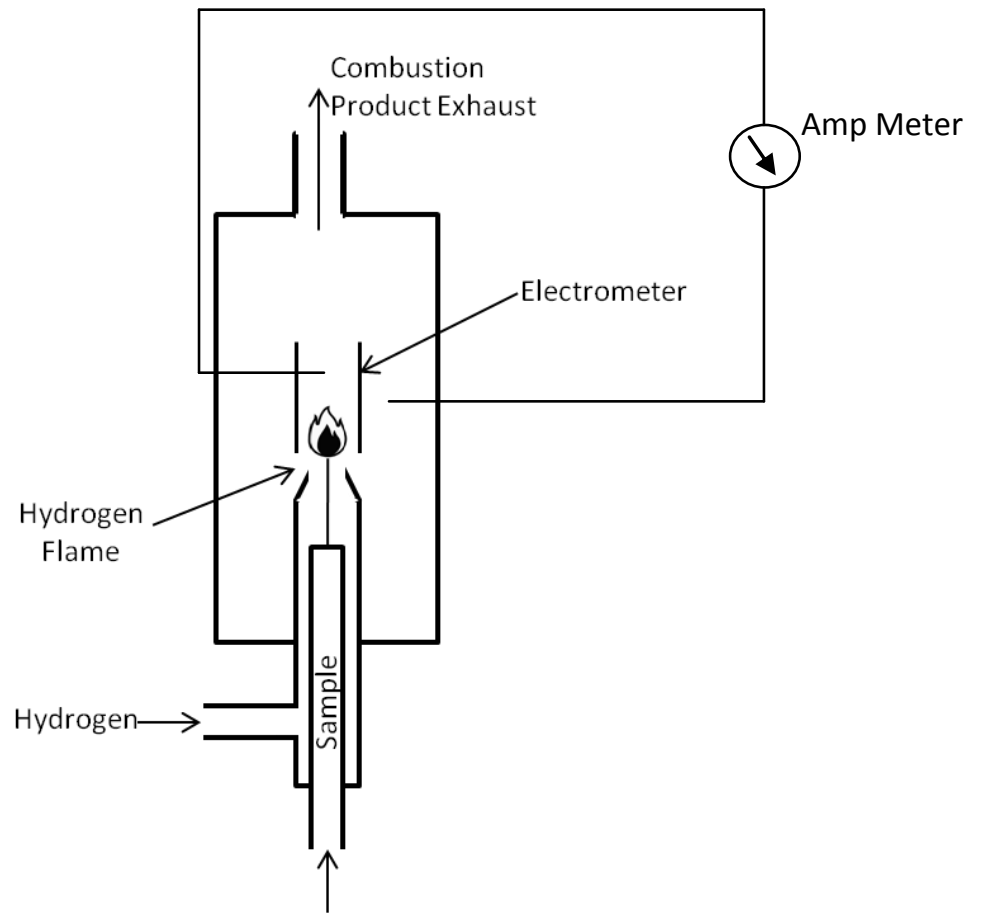

Figure 2: Diagram of FID Type Analyzer [16]

\section{Gas Chromatograph (GC)}

A gas chromatograph is commonly used for identifying species, and species concentration, present in a sample. The following description of this analyzers function is based on the content covered in the book Continuous Emissions Monitoring [14]. However, instead of burning the sample it mixes an inert gas (carrier gas), such as nitrogen, with the sample. This mixture is drawn into a column where it is passed over an electrical element sensitive to the components present in the gas mixture. Similar to the FID detector, the gases emitted electrons creates a current response indicative of the specific gas and concentration present. It is not uncommon for this detector and an FID type detector to be used together to help identify 
concentrations of molecules that are more difficult to analyze. For example a GC-FID type detector is used by the Mexa analyzing systems to measure methane concentration in the exhaust sample.

\section{Chemiluminescent Detector}

A chemiluminescent detector measures the intensity of light produced by a chemical reaction and its output is related to the concentration of a particular compound present in a sample. A CLD is used in the Mexa system, as a means to detect and measure $\mathrm{NO}_{\mathrm{x}}$ presence. A CLD is based on NO reactions with ozone $\left(\mathrm{O}_{3}\right)$. To ensure a complete reaction of the NO, the CLD must first produce an excess of ozone by reacting oxygen $\left(\mathrm{O}_{2}\right)$ in a quartz chamber. The ozone is then allowed to interact with the exhaust sample thus producing photons proportional to the $\mathrm{NO}_{\mathrm{x}}$ concentration. The emitted photons are measured by a photomultiplier and converted to voltage that is proportional to the $\mathrm{NO}$ concentrations.

\subsubsection{Soot Concentration Measurements}

Concentration of soot emissions were measured using the AVL 483 Micro Soot Sensor. The AVL 483 Micro Soot Sensor uses the photo-acoustic method to measure soot emissions. This system is a highly sensitive and is capable of detecting soot levels as low as $5 \mu \mathrm{g} / \mathrm{m}^{3}$. The sensing technique used by the AVL Micro Soot Sensor also allows for transient soot measurement; conditions commonly associated with an engine accelerations and/or load changes. 


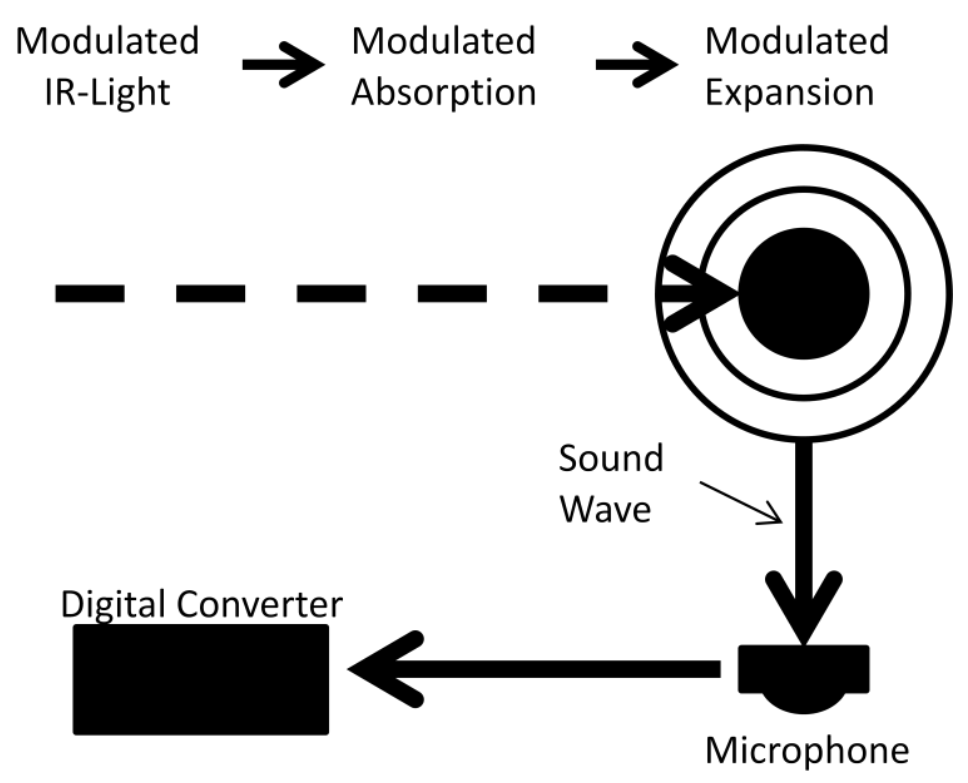

Figure 3: AVL Micro Soot Sensor Photo Acoustic Method [17]

A raw exhaust sample is pumped into the AVL sensor (by an on-board pump), where a modulated infrared light is passed through the sample. As the light passes through the sample the molecules are excited; which results in a molecule reaction of molecule expanding and contracting rapidly. The vibration of the molecules present in the exhaust sample creates sound waves within the sensor's test chamber that can be detected by a microphone and translated into a soot concentration. This is the process depicted in Figure 3.

The only issue associated with the AVL system is that the sensors lens occasionally needs to be cleaned of any residual soot accumulation so that the test measurements remain accurate and consistent. Figure 4, shows the AVL unit installed in EERL engine test cell. 


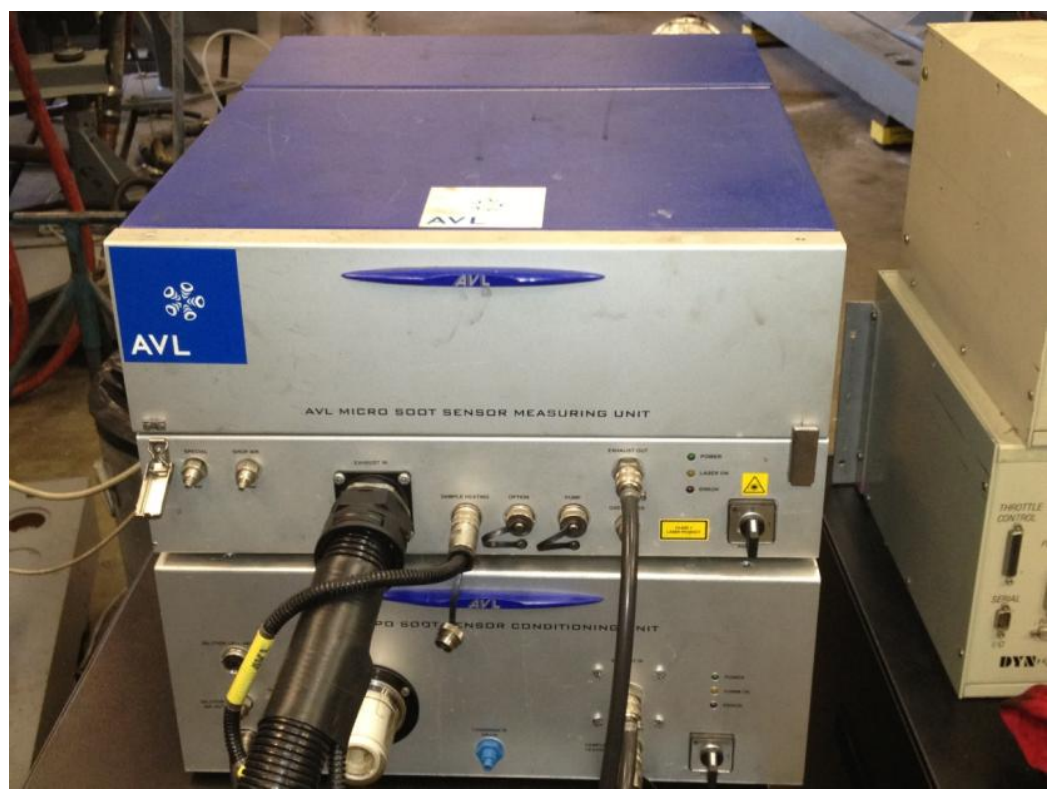

Figure 4: AVL 483 Micro Soot Sensor

\subsubsection{Particulate Matter (PM)}

As previously mentioned, this study did not measure PM emissions; however, it is important to understand what PM is and how it is measured. PM is principally elemental carbon (EC) with other unburned and unburned chemicals, or materials, adsorbed on the surface following combustion. These chemicals and materials vary, depending upon fuel and mode of combustion but are most commonly: unburned hydrocarbons, sulfates, wear materials, and water [18]. Particulate matter emissions maybe measured gravimetrically and/or by measuring the concentration and size distribution with particle sizing instruments. This works by passing and exhaust sample, from a system's secondary dilution tunnel (where Mexa sample was drawn), through a preconditioned filter. This filter is conditioned in a clean room and its weight measured and recorded prior to testing. Following testing the filter is again placed in the clean room for a period of time for equilibration. After the filter is equilibrated the PM filter is again weighed, and the resulting difference in weight represents the PM mass. 


\subsection{Test Procedure}

As described in Section 3.4.3, with the test engine properly mounted on the dynamometer, the diesel engine's exhaust was routed through the CVS dilution tunnel. The engine was connected to a heat exchanger through which engine coolant fluid was cycled via the engine's water pump. The engine's air intake was linked to the in-house air supply so that the intake air is of a consistent mixture and temperature conditions.

Concurrent to the engine installation, the aforementioned testing systems had to be setup and calibrations were conducted. These included, but were not limited to: analyzer calibrations, analyzer interference checks, converter efficiency checks, and CVS verification. Finally, the lubricating oil was added to the test engine.

The first step of each engine test was to purge the engine's fuel system with diesel fuel and conduct the initial engine evaluation test, which includes fuel stabilization and conditioning of the test engine/measurement system. Next, the baseline engine test began with the certification fuel. This established the baseline emission level for that particular test engine.

With the engine tests using D2 diesel completed, the VO fuel system, as previously discussed in Section 3.2, was used to accommodate the switch to VO. To accomplish this, the VO fuel system was installed by connecting the fuel tank/system directly in place of the typical fuel system. Following the fuel system installation, the engine was started and injection timing adjusted by using the Drivven Control system. Next the engine test of $100 \%$ VO fuel operation was run and emissions results were recorded. Likewise, the remaining engine tests for load and speed were conducted and emission results recorded. Again to keep tests as consistent and possible, the VO fuel tests were completed with $100 \%$ VO, rather that the dual fuel system which would be used in applications. 


\section{Discussion of Results}

This chapter discusses and compares the results found during the course of this study. It will start by first introducing the recorded data taken during testing, as well as showing the standard deviations recorded for each measurement and its associated coefficient of variation. The remaining sections will present and compare the individual exhaust emissions species observed during the study.

\subsection{Laboratory Results for D2 Diesel}

The following tabulated results are the average brake specific mass exhaust emissions emitted during each of the engine's three final test runs. Several runs up to this point were required as a means of setting up the test system. These included runs to confirm proper fuel injection mapping for optimal engine operation and runs to confirm the maximum torque output of the test engine. Table 9 shows the average emissions recorded for test runs, for which the test report summaries are included in the appendix of this thesis. Since this table shows the averaged values recorded for the three tests run for the baseline D2 diesel fuel. The standard deviation and coefficient of variation for each average value presented below can be found in Table 9 . 
Table 9: Brake Specific Exhaust Emissions from Baseline D2 Diesel Runs

\begin{tabular}{|c|c|c|c|c|c|c|}
\hline & THC(g/bhp-hr) & $\mathrm{CO}$ (g/bhp-hr) & $\mathrm{CO}_{2}$ (g/bhp-hr) & $\mathrm{NO}_{\mathrm{x}}(\mathrm{g} / \mathrm{bhp}-\mathrm{hr})$ & NO (g/bhp-hr) & Soot (mg/bhp-hr) \\
\hline Mode 1 & 0.34 & 28.36 & 571.23 & 4.01 & 3.57 & 293.99 \\
\hline Mode 2 & 1.06 & 5.46 & 619.23 & 1.90 & 1.70 & 0.89 \\
\hline Mode 3 & 0.34 & 2.12 & 551.17 & 7.04 & 6.25 & 15.56 \\
\hline Mode 4 & 0.10 & 15.84 & 542.47 & 5.50 & 4.74 & 267.44 \\
\hline Mode 5 & 0.63 & 2.85 & 612.47 & 3.53 & 3.08 & 1.54 \\
\hline Mode 6 & 0.31 & 0.37 & 535.53 & 5.28 & 4.62 & 5.26 \\
\hline \multicolumn{7}{|c|}{ STANDARD DEVIATION (g/bhp-hr) } \\
\hline & THC & $\mathrm{CO}$ & $\mathrm{CO}_{2}$ & $\mathrm{NO}_{\mathrm{x}}$ & NO & Soot \\
\hline Mode 1 & 0.03 & 0.47 & 2.44 & 0.05 & 0.08 & 23.05 \\
\hline Mode 2 & 0.06 & 0.37 & 2.31 & 0.12 & 0.11 & 0.03 \\
\hline Mode 3 & 0.01 & 0.18 & 0.21 & 0.16 & 0.11 & 1.65 \\
\hline Mode 4 & 0.01 & 0.99 & 2.75 & 0.15 & 0.16 & 28.79 \\
\hline Mode 5 & 0.02 & 0.11 & 1.01 & 0.04 & 0.02 & 0.14 \\
\hline Mode 6 & 0.01 & 0.01 & 0.81 & 0.01 & 0.02 & 0.30 \\
\hline \multicolumn{7}{|c|}{ COV (-) } \\
\hline & THC & $\mathrm{CO}$ & $\mathrm{CO}_{2}$ & $\mathrm{NO}_{\mathrm{x}}$ & $\mathrm{NO}$ & Soot \\
\hline Mode 1 & 0.10 & 0.02 & 0.00 & 0.01 & 0.02 & 0.08 \\
\hline Mode 2 & 0.06 & 0.07 & 0.00 & 0.06 & 0.06 & 0.03 \\
\hline Mode 3 & 0.03 & 0.08 & 0.00 & 0.02 & 0.02 & 0.11 \\
\hline Mode 4 & 0.06 & 0.06 & 0.01 & 0.03 & 0.03 & 0.11 \\
\hline Mode 5 & 0.04 & 0.04 & 0.00 & 0.01 & 0.01 & 0.09 \\
\hline Mode 6 & 0.05 & 0.02 & 0.00 & 0.00 & 0.00 & 0.06 \\
\hline
\end{tabular}

\subsection{Laboratory Results for VO Fuel}

Following the conclusion of the baseline tests the VO fuel system was installed. Again a preliminary test run was made to insure that the testing setup had not unexpectedly changed and that the engine was operating correctly. Once this test run was complete and successful operation confirmed, the same three evaluation runs were made using the VO fuel. Below, Table 10 is the averaged data taken from these three runs. Similar to the baseline runs this table represents the data taken from the three VO fuel test runs collected. The standard deviation and coefficient of variation for each average value presented below can be found in Table 10 . 
Table 10: Brake Specific Exhaust Emissions from VO Fuel Runs

\begin{tabular}{|c|c|c|c|c|c|c|}
\hline & THC (g/bhp-hr) & $\begin{array}{c}\mathrm{CO}(\mathrm{g} / \mathrm{bhp}- \\
\mathrm{hr})\end{array}$ & $\mathrm{CO}_{2}$ (g/bhp-hr) & $\mathrm{NO}_{\mathrm{x}}(\mathrm{g} / \mathrm{bhp}-\mathrm{hr})$ & $\begin{array}{c}\text { NO (g/bhp- } \\
h r)\end{array}$ & Soot (mg/bhp-hr) \\
\hline Mode 1 & 0.75 & 10.57 & 599.83 & 4.19 & 4.23 & 83.77 \\
\hline Mode 2 & 1.09 & 3.37 & 632.70 & 3.02 & 3.05 & 178.21 \\
\hline Mode 3 & 0.65 & 2.75 & 614.50 & 4.96 & 5.01 & 71.16 \\
\hline Mode 4 & 0.21 & 18.68 & 631.27 & 4.21 & 4.22 & 403.99 \\
\hline Mode 5 & 0.46 & 2.09 & 627.73 & 3.57 & 3.59 & 8.08 \\
\hline Mode 6 & 0.29 & 0.86 & 638.27 & 4.61 & 4.63 & 4.40 \\
\hline \multicolumn{7}{|c|}{ STANDARD DEVIATION (g/bhp-hr) } \\
\hline & THC & $\mathrm{CO}$ & $\mathrm{CO}_{2}$ & $\mathrm{NO}_{\mathrm{x}}$ & NO & Soot \\
\hline Mode 1 & 0.060 & 0.045 & 1.504 & 0.028 & 0.031 & 3.844 \\
\hline Mode 2 & 0.123 & 0.044 & 2.390 & 0.056 & 0.021 & 24.913 \\
\hline Mode 3 & 0.033 & 0.026 & 3.897 & 0.016 & 0.016 & 5.187 \\
\hline Mode 4 & 0.007 & 3.178 & 0.473 & 0.137 & 0.141 & 35.693 \\
\hline Mode 5 & 0.029 & 0.054 & 0.833 & 0.019 & 0.016 & 1.170 \\
\hline Mode 6 & 0.026 & 0.071 & 0.924 & 0.049 & 0.044 & 0.310 \\
\hline \multicolumn{7}{|c|}{$\operatorname{cov}(-)$} \\
\hline & $\mathrm{THC}$ & $\mathrm{CO}$ & $\mathrm{CO}_{2}$ & $\mathrm{NO}_{\mathrm{x}}$ & NO & Soot \\
\hline Mode 1 & 0.079 & 0.004 & 0.003 & 0.007 & 0.007 & 0.046 \\
\hline Mode 2 & 0.113 & 0.013 & 0.004 & 0.018 & 0.007 & 0.140 \\
\hline Mode 3 & 0.051 & 0.009 & 0.006 & 0.003 & 0.003 & 0.073 \\
\hline Mode 4 & 0.033 & 0.170 & 0.001 & 0.032 & 0.033 & 0.088 \\
\hline Mode 5 & 0.062 & 0.026 & 0.001 & 0.005 & 0.004 & 0.145 \\
\hline
\end{tabular}

\subsection{Comparison of Both Test Fuels}

\subsection{1 $\quad \mathrm{NO}_{\mathrm{x}}$ and NO Emissions Comparison}

Brake-specific mass $\mathrm{NO}_{\mathrm{x}}$ emissions observed during testing were consistent with the baseline D2 diesel fuel, seen by inspection of Figure 5. Ultimately, it was observed that the greatest difference in $\mathrm{NO}_{\mathrm{x}}$ production between $\mathrm{D} 2$ diesel and $\mathrm{VO}$ was found to be approximately 29\%. This behavior was recorded mid test run, during mode 3 and is illustrated by Figure 54. In the figure it is apparent that it is, in fact, the baseline $\mathrm{D} 2$ diesel that produced the greater $\mathrm{NO}_{\mathrm{x}}$ 
emissions during mode 3. Additionally, for further clarification mode 3 is the engine being at the lower speed (1800 rpm) and at 50\% load. Finally, VO emissions were also notably higher for mode 2, a low speed light load test case. This difference was found to be approximately $37 \%$.

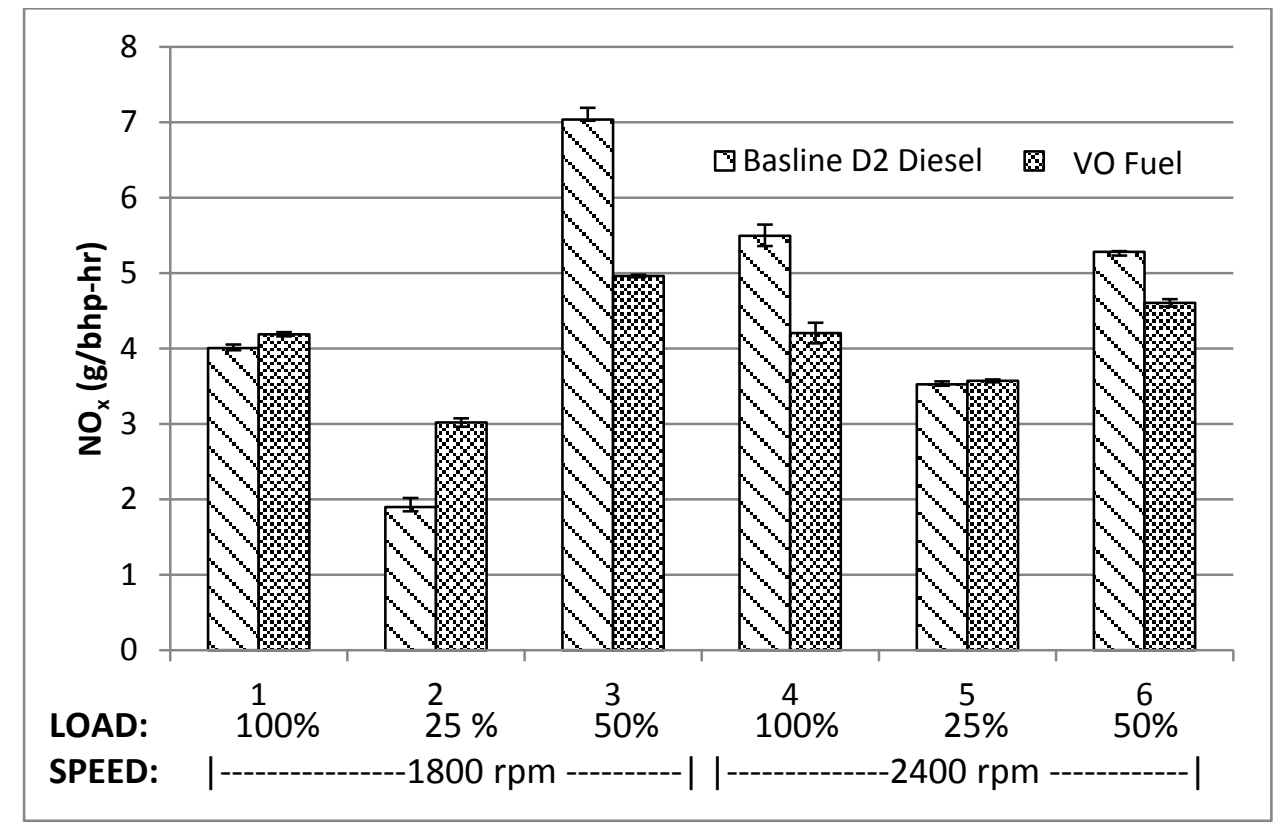

Figure 5: $\mathrm{NO}_{\mathrm{x}}$ Emissions

Similar to the $\mathrm{NO}_{\mathrm{x}}$ production, nitric oxide production also is greatest for the engine operating on D2 diesel at $50 \%$ load and at low speed. However, the percentage difference between the two fuels at mode three is less, at approximately 17\%. Figure 6 depicts the trends described for the NO emissions measured. In addition to the elevated diesel emission at mode 3, elevate emissions for VO was recorded for modes 1, 2, and 3. These were 15\%, 40\%, and 33\% respectfully. 


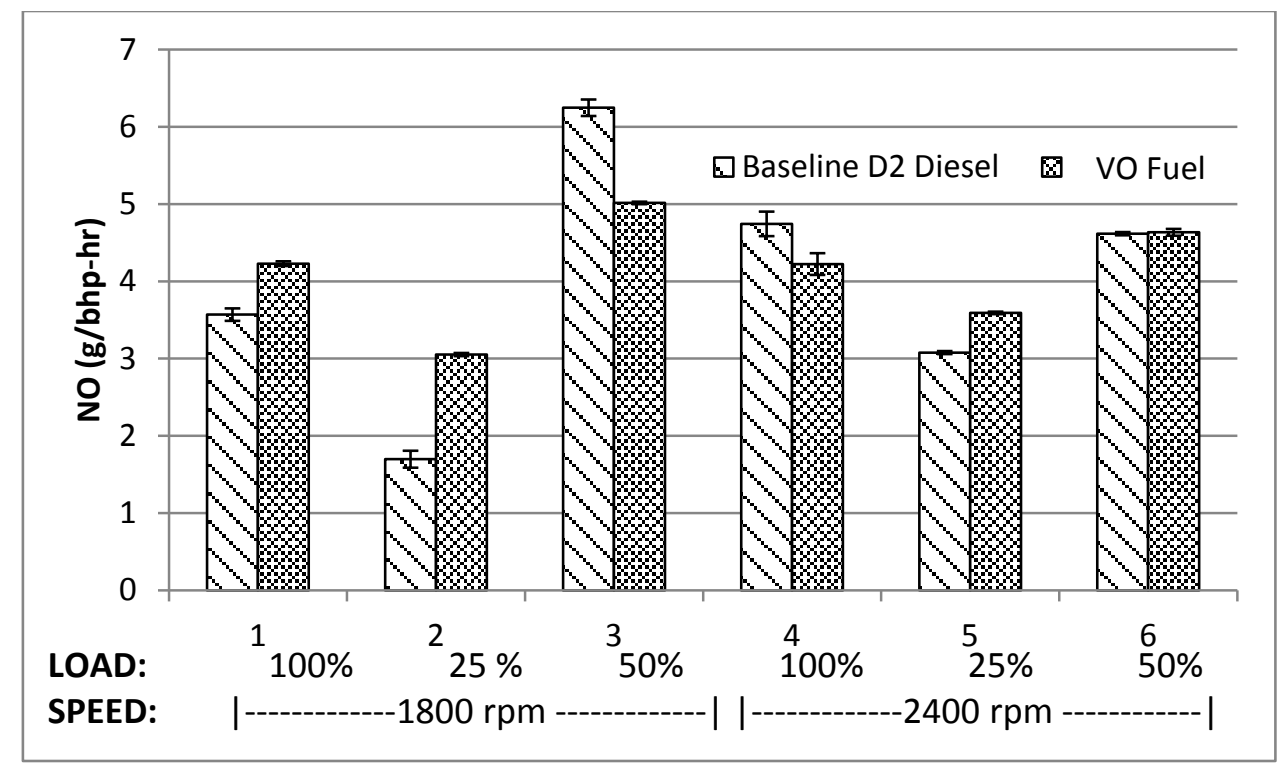

Figure 6: NO Emissions

\subsubsection{Measured Soot Emission Comparison}

Figure 7 shows a comparison of soot emissions for D2 and VO fuels. Apart from the high brake-specific soot emissions from the D2 diesel in mode 1, VO fuel emitted higher brakespecific soot in all other modes of testing. It is evident from Figure 7, that VO soot emissions were higher for all modes except for mode 1 and mode 6 , which shows that D2 is $51.1 \%$ higher than the VO. 


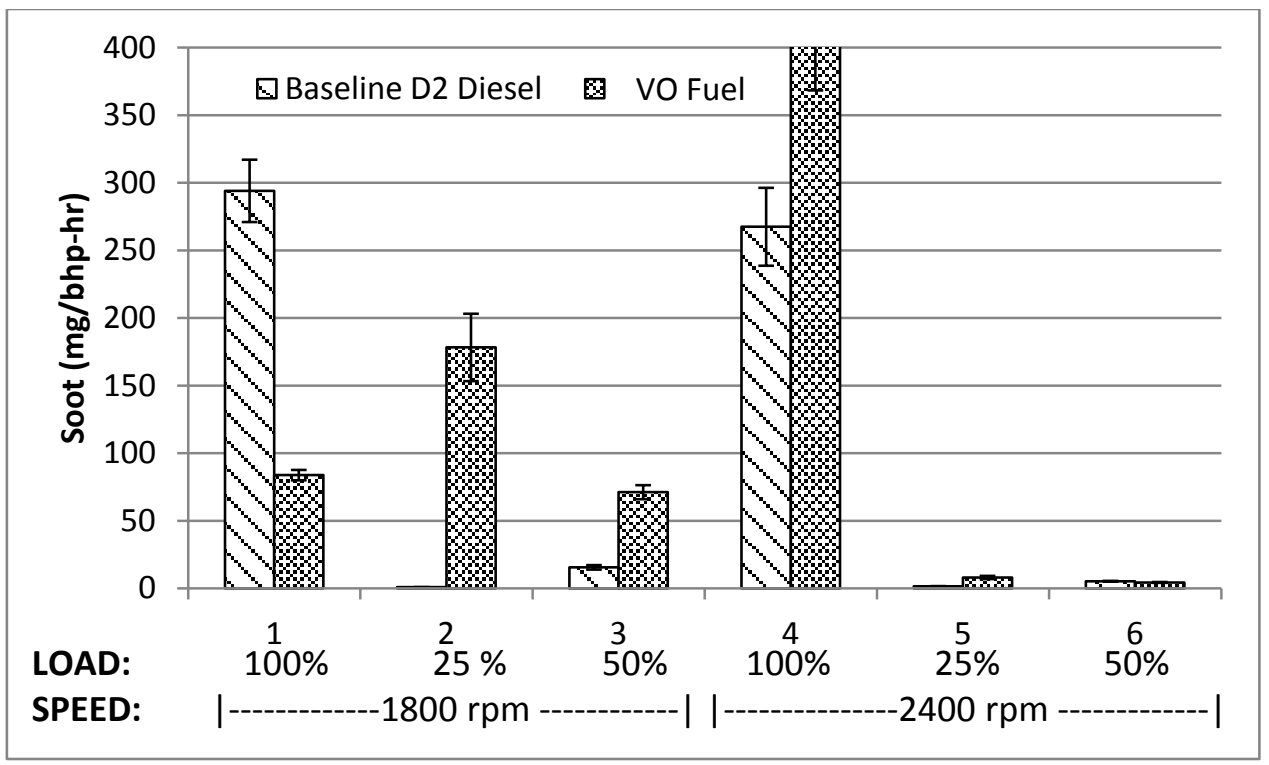

Figure 7: Soot Emissions

\subsubsection{Other Regulated Constituents (THC, $\mathrm{CO}$, and $\mathrm{CO}_{2}$ ) Comparison}

Of the other three regulated constituents the highest emissions increase noticed was in regards to total brake-specific mass hydrocarbon emissions (BSHC). Most notably the low speed tests modes (modes 1 through 3). Specifically, modes 1 and 3 show an approximate 50\% increase in BSHC emissions. However, when examining the graph, Figure, for higher speed modes (modes 4 to 6 ) it can be seen that the BSHC emissions between the two fuels is more similar. Additionally, there is a noticeably higher BSHC emission for the D2 fuel for mode 5 of about $33 \%$. This particular mode is the engine operating at $2400 \mathrm{rpm}$ and $50 \%$. 


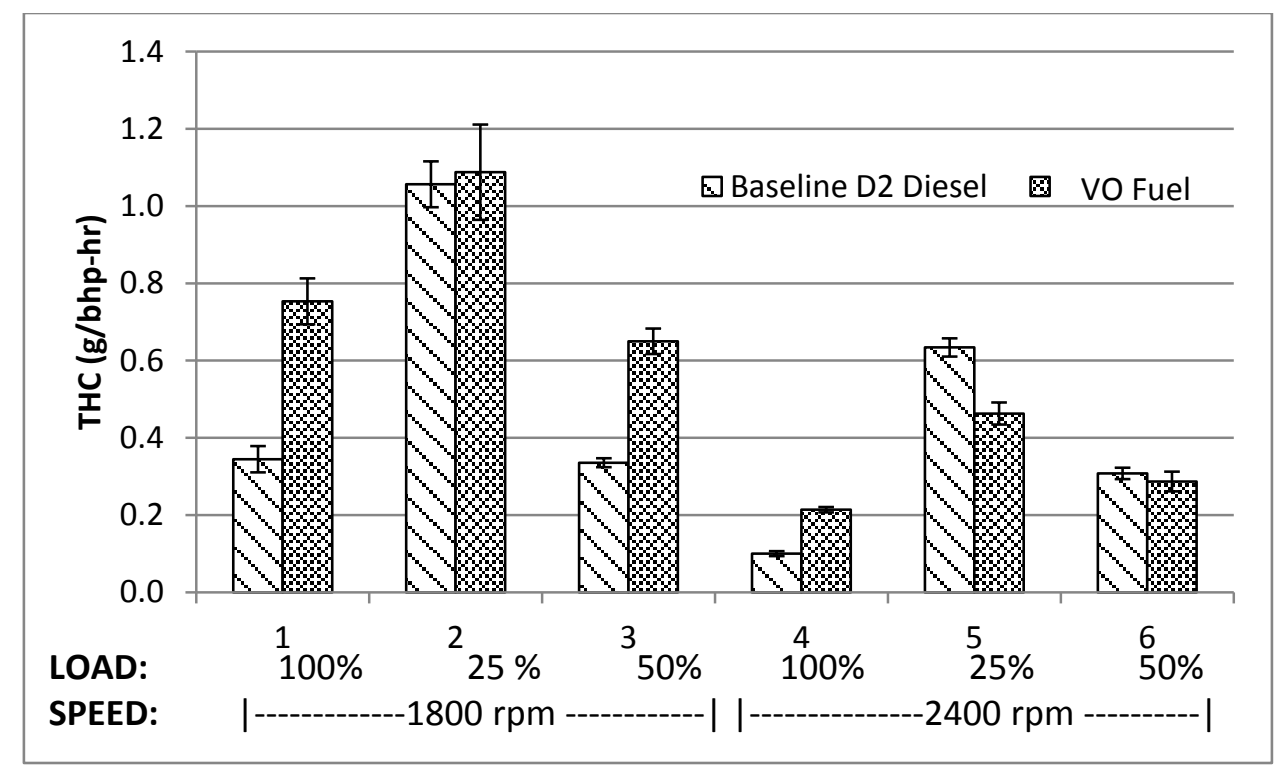

Figure 17: Brake-Specific Total Hydrocarbon Emissions

The most significant reduction observed throughout testing was in regards to $\mathrm{CO}$

emissions. Figure shows the per-modal data recorded as well as the significant spike in CO emitted for $\mathrm{D} 2$ diesel during mode 1 . The greatest decrease, $64 \%$, in $\mathrm{CO}$ was observed when the engine was operating on VO fuel at low speed and $100 \%$ load.

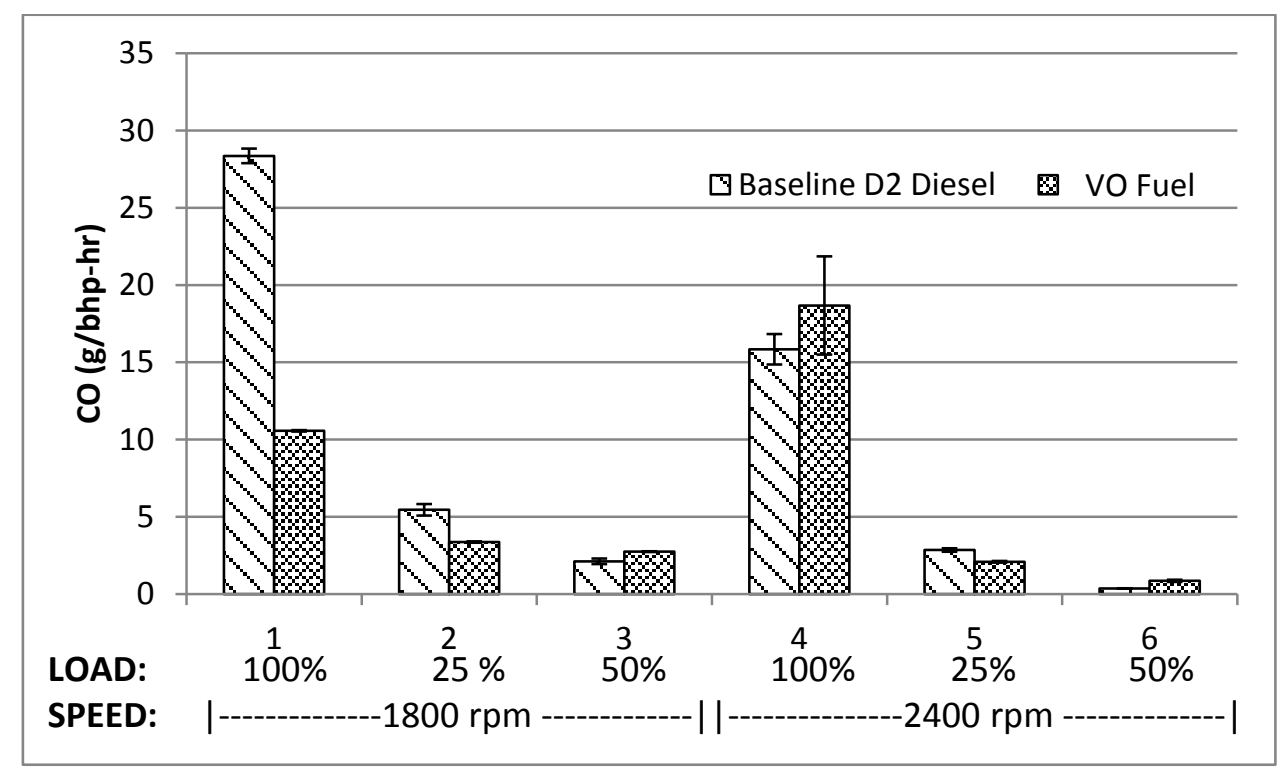

Figure 18: Brake-specific CO Emissions 
The final constituent recorded was $\mathrm{CO}_{2}$ emissions. Little variation $\mathrm{CO}_{2}$ was noticed over the course of engine testing. The greatest differences experienced were when the engine was run at $50 \%$ load, seen in modes 3 and 6 in Figure. The percentage increase for modes 3 and 6 were $12 \%$ and $17 \%$ respectively, when operating on VO fuel.

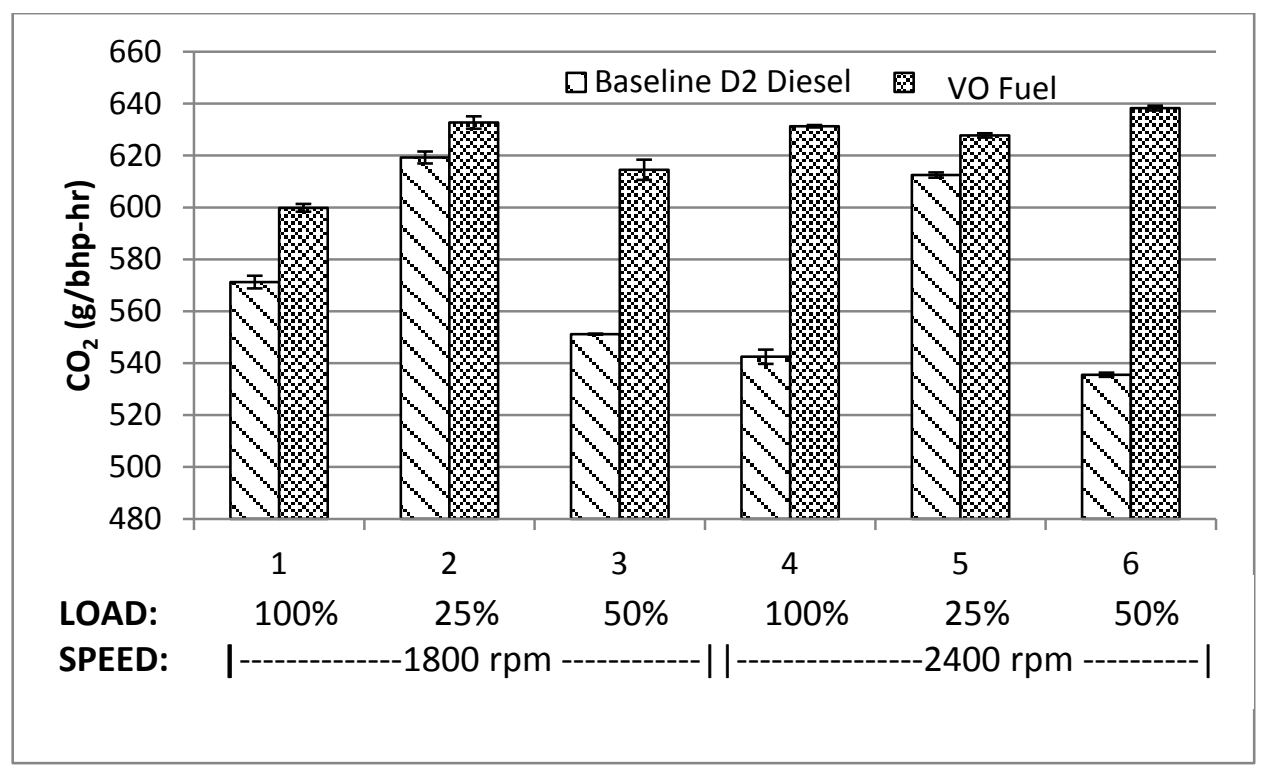

Figure 19: Brake-Specific $\mathrm{CO}_{2}$ Emissions

\subsection{Fuel Economy}

Fuel economy was observed to only slightly vary between the two test fuels. The greatest fuel consumptions, a $15 \%$ and $16 \%$ increase, observed for high speed operating on VO during modes 4 and 6 . The fuel economy analysis data is provided in Table 11. Figure shows how the engine's fuel economy varied between modes for each of the two fuels tested. 
Table 11: Fuel Economy Analysis

\begin{tabular}{|c|c|c|c|c|c|c|c|c|}
\hline & \multicolumn{4}{|c|}{ D2 Diesel Fuel Consumption (g/bhp-hr) } & \multicolumn{4}{|c|}{ VO Fuel Consumption (g/bhp-hr) } \\
\hline & \multirow{2}{*}{$\begin{array}{c}\text { Test ID: } \\
\text { 0030-002- } \\
05 \\
\end{array}$} & \multirow{2}{*}{$\begin{array}{c}\text { Test ID: } \\
\text { 0030-002- } \\
06 \\
\end{array}$} & \multirow{2}{*}{$\begin{array}{l}\text { Test ID: } \\
\text { 0030-002- } \\
07\end{array}$} & \multirow[b]{2}{*}{ AVG } & \multirow{2}{*}{$\begin{array}{c}\text { Test ID: } \\
\text { 0030-004- } \\
02\end{array}$} & \multirow{2}{*}{$\begin{array}{c}\text { Test ID: } \\
\text { 0030-004- } \\
03\end{array}$} & \multirow{2}{*}{$\begin{array}{c}\text { Test ID: } \\
\text { 0030-004- } \\
04\end{array}$} & \multirow[b]{2}{*}{ AVG } \\
\hline & & & & & & & & \\
\hline Mode 1 & 190.6 & 192.3 & 192.4 & 191.7 & 195.4 & 193.6 & 194.5 & 194.5 \\
\hline Mode 2 & 200.3 & 199.1 & 200.0 & 199.8 & 204.6 & 202.1 & 201.7 & 202.8 \\
\hline Mode 3 & 173.7 & 173.0 & 172.7 & 173.1 & 193.8 & 194.6 & 194.0 & 194.1 \\
\hline Mode 4 & 175.7 & 178.6 & 176.3 & 176.9 & 205.5 & 207.7 & 209.2 & 207.5 \\
\hline Mode 5 & 194.2 & 194.2 & 195.2 & 194.5 & 199.2 & 199.6 & 198.5 & 199.1 \\
\hline Mode 6 & 168.7 & 169.3 & 169.0 & 169.0 & 200.7 & 201.7 & 201.3 & 201.2 \\
\hline
\end{tabular}

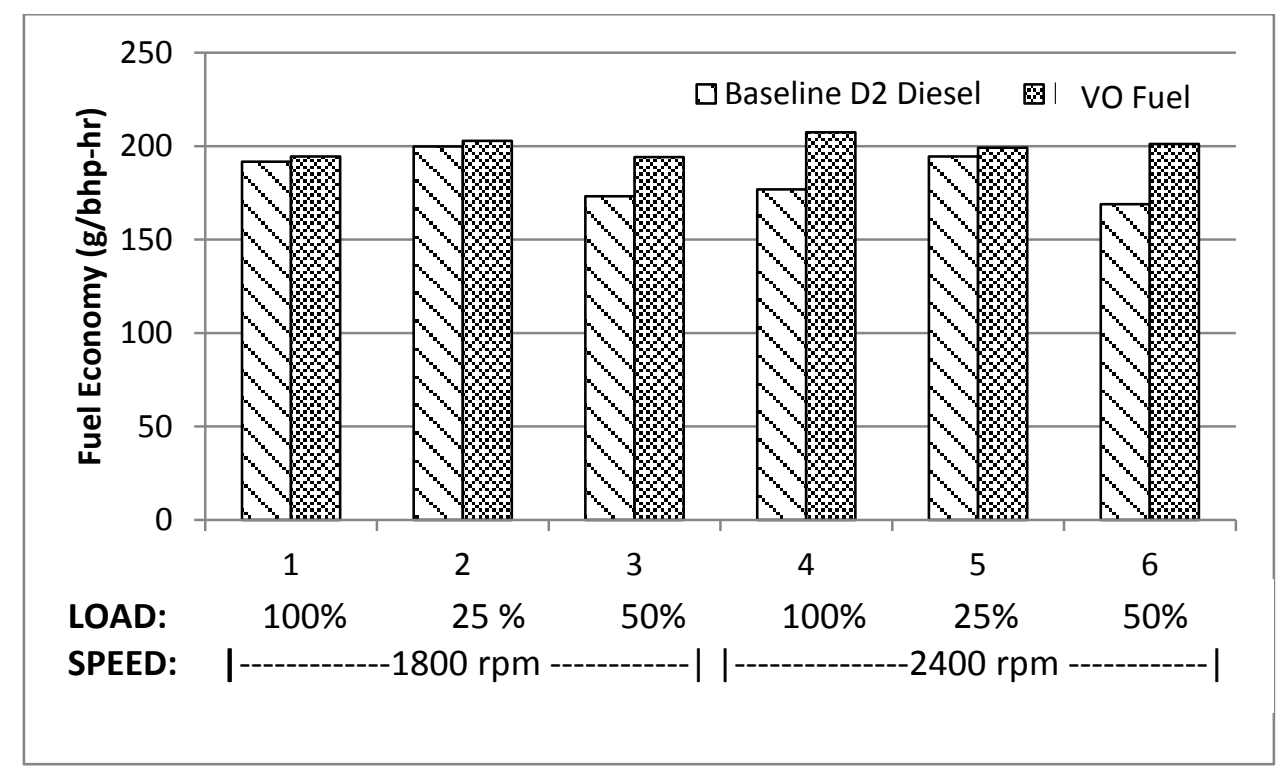

Figure 20: Fuel Economy Comparison

\subsection{Exhaust Temperature Review}

Since no in cylinder pressure data was available during this test, the best way to predict the combustion behavior inside the engine was review the exhaust temperatures of the engine as it ran through each test mode for both of the fuels tested. Since pressure and temperature are directly related through the ideal gas law, it can be inferred that if a relatively high temperature is recorded that a equally high pressure would have occurred. Likewise, if high in cylinder pressure 
is indicative of good or complete combustion, than a high temperature can also be associated with good combustion. Table 12 shows the exhaust temperature measurements taken during the course of testing.

Table 12: Exhaust Temperature Measurements

\begin{tabular}{|c|c|c|c|c|c|c|c|c|}
\cline { 2 - 8 } \multicolumn{1}{c|}{} & \multicolumn{2}{c|}{ D2 Diesel Fuel Exhaust Temp (deg C) } & \multicolumn{3}{c|}{ VO Fuel Exhaust Temp (deg C) } \\
\cline { 2 - 9 } \multicolumn{1}{c|}{} & $\begin{array}{c}\text { Test ID: } \\
\text { 0030-002- } \\
\text { 05 }\end{array}$ & $\begin{array}{c}\text { Test ID: } \\
\text { 0030-002- } \\
\text { 06 }\end{array}$ & $\begin{array}{c}\text { Test ID: } \\
\text { 0030-002- } \\
\text { 07 }\end{array}$ & AVG & $\begin{array}{c}\text { Test ID: } \\
\text { 0030-004- } \\
\text { 02 }\end{array}$ & $\begin{array}{c}\text { Test ID: } \\
\text { 0030-004- } \\
\text { 03 }\end{array}$ & $\begin{array}{c}\text { Test ID: } \\
\text { 0030-004- } \\
\text { 04 }\end{array}$ & AVG \\
\hline Mode 1 & 691.2 & 697.2 & 708.6 & 699.0 & 706 & 704.2 & 704.7 & 705.0 \\
Mode 2 & 398.2 & 399 & 403.9 & 400.4 & 384.6 & 383.9 & 385.2 & 384.6 \\
Mode 3 & 504.7 & 500.6 & 502.5 & 502.6 & 540.8 & 540.9 & 542.4 & 541.4 \\
Mode 4 & 729.2 & 758 & 737.8 & 741.7 & 857.4 & 864.5 & 866 & 862.6 \\
Mode 5 & 410.6 & 415.8 & 412.4 & 412.9 & 411.2 & 418.3 & 417.2 & 415.6 \\
Mode 6 & 513.9 & 511.9 & 514.9 & 513.6 & 567.1 & 568.2 & 566.1 & 567.1 \\
\hline
\end{tabular}




\section{Conclusions and Recommendations}

\subsection{Conclusions}

The findings of this research effort suggest that the steady-state engine performance of a VO fueled engine as compared to diesel fuel is similar and. As a result, VO may serve as an effective alternative fuel. Unfortunately, since the VO fuel requires preheating fuel prior to use, the use of VO as a fuel is less advantageous. Particularly because current VO systems use the engine running on diesel at startup and shutdown as a method for heating VO fuel prior to use, and to purge the fuel system.

The startup and shutdown issue is directly associated with the higher viscosity of vegetable oil. Because of VO's viscosity, particularly when cold, it does not flow as easily through the fuel system and if present after shutdown the VO can cause flow obstructions. The after-market devices used to convert the diesel engines negate this problem by using a dual-fuel process.

The dual fuel approach uses diesel during startup and shutdown. During startup, diesel fuel is used until the engine reaches its normal operating temperature. Likewise, during shutdown, diesel fuel is again introduced to flush all VO from the system. During engine operation, at normal operating temperatures, the aftermarket device preheats the $\mathrm{VO}$, thereby lowering its viscosity to appoint that is readily usable by a traditional diesel engine.

Therefore, this research effort suggests that $\mathrm{VO}$ is a reasonable alternative fuel if an engine is modified to accommodate for startup and shutdown. It would seem reasonable to believe that should VO become a commonly used fuel source, that engine designers would 
incorporate design changes simplify the operation of dual fuel vehicles, or possibly devise other means of reliable heating the $\mathrm{VO}$ to achieve the required lower viscosities.

\subsection{Recommendations}

From the tests and analysis conducted through this research, it appears that VO is a viable alternative for diesel engines. That said, and as previously discussed, the majority of the overthe-counter aftermarket conversion units require varying amounts of operator intervention. It seems logical that in order to develop a growing VO usage/market, there will have to be more electronically/computer controlled systems available to make these systems more appealing to the everyday driver. Additionally, research may be necessary to address the VO supply vs. demand issue. 


\section{Works Cited}

[1] M. Z. Jacobson and M. A. Delucchi, "A Pathe To Sustainable Energy By 2030," Scientific American: A Plan for a Sustainable Future, pp. 58-65, November 2009.

[2] European Commission, "COMMUNICATION FROM THE COMMISSION TO THE EUROPEAN UNION - Energy 2020, A strategy for competitive, sustainable and secure energy," European Commission, Brussels, 2010.

[3] P. Fairley, "Next generation biofuels," Nature, pp. S2-S5, 23 June 2011.

[4] S. L. Nettles-Anderson and D. B. Olsen, "Survey of Straight Vegetable Oil Composition Impact on Combustion Properties," SAE International, Warrendale, 2009. 2009-01-0487

[5] G. Knothe, "Historical perspectives on vegetable oil-based diesel fuels," Inform, Volume 12, November 2001, pp. 103-1107, Danvers, MA

[6] G. Knothe, J. V. Gerpen and J. Krahl, The Biodiesel Handbook, Urbana: AOCS Press, 2005.

[7] POPDiesel,"The POP Diesel Fuel System," 2012. [Online]. Available: http://www.popdiesel.com/pop_diesel_fuel.htm. [Accessed 19 January 2012],Albuquerque, NM.

[8] A. Y. Deshmukh, "Technical and Economical Feasibility of Biofuels for Engine Applications," SAE International, 2009.

[9] Fattywagons.com, "Installation Instructions," 2007. [Online]. Available: http://www.fattywagons.com/install\%20page.htm. [Accessed 23 January 2012].

[10] M. Vojtisek-Lom, "Time-resolved Emissions Characteristics of Modern Passenger Vehicle Diesel Engines Powered by Heated Vegetable Oil," SAE, Naples, 2007, 2007-24-0129.

[11] West Virginia University Center for Alternative Fuels, Engines and Emissions, "West Virginia University - CAFEE," WVU, 1 April 2012. [Online]. Available: http://cafee.wvu.edu/. [Accessed 10 April 2012], Morgantown, WV.

[12] OMEGA, " Economical Liquid Turbine Flowmeters," OMEGA Engineering Inc., May 2012. [Online]. Available: http://www.omega.com/ppt/pptsc.asp?ref=FTB1300_SERIES [Accessed 24 May 2012], Stamford CT, 2012.

[13] HORIBA, "MEXA-7200SLE," 2012. [Online]. Available: http://www.horiba.com/automotive-test-systems/products/emission-measurementsystems/analytical-systems/standard-emissions/details/mexa-7200sle-901/. [Accessed 2 Febuary 2012] Kyoto, Japan.

[14] A. J. James, Continuous Emission Monitoring - Second Edition, New York: John Wiley \& Sons, Inc., 2000.

[15] D. A. Reckhow and G. Makdissy, "MISCELLANEOUS INSTRUMENTAL METHODS," 
17 June 2011. [Online]. Available:

http://www.ecs.umass.edu/cee/reckhow/courses/572/572bk22/572BK22.html. [Accessed 3 Febuary 2012], UMass Amherst College of Engineering, Amherst MA.

[16] R. Scott, "The Flame Ionization Detector (FID)," 2008. [Online]. Available: http://www.chromatography-online.org/Chrial-GC/The-Flame-Ionization-DetectorFID.html. [Accessed 3 Febuary 2012], Library4science, Letchworth Garden City UK.

[17] AVL, "AVL Micro Soot Sensor - Transient High Sensitive Soot Measurement," AVL LIST GMBH, Graz, Austria, 2010.

[18] J. B. Heywood, Internal Combustion Engine Fundamentals, New York: McGraw-Hill, Inc., 1988. 
7. Appendix 
Type: Steady-State

Test ID: 0030-002-05

Test Started: 2011-11-12 15:04:08

Program Version: 1.0.4333.21901

Comments: Hot Start 7-mode; Haltermann

* mode 1 was used for calibration and data was not use

Mode

Average Speed (rpm)

Average Torque (ft-lb)

Total Work (bhp-hr)

$\mathrm{HC}(\mathrm{g} / \mathrm{s})$

$\mathrm{HC}$ (g/bhp-hr)

$\mathrm{Kh}$

NOx (g/s)

Secondary NOx (g/s)

NOx (g/bhp-hr)

Secondary NOx (g/bhp-hr)

$\mathrm{CO}(\mathrm{g} / \mathrm{s})$

$\mathrm{CO} 2(\mathrm{~g} / \mathrm{s})$

$\mathrm{CO} 2$ (g/bhp-hr)

$\mathrm{CO}$ (g/bhp-hr)

Gaseous VMix (scf)

Secondary Dilution Flow

(scf)

Total PM Flow (scf)

Fuel Mass Carbon Balance

(g)

Intake Air Volume (scf)

Fuel Mass Gravimetric (g)

EGR Fraction (\%)

Intake $\mathrm{O} 2$ (\%)

Exhaust $\mathrm{O} 2$ (\%)

BMEP (bar)

Engine $\mathrm{HC}$ (ppm)

Engine NOx (ppm)

Engine CO (ppm)

CO2 (ppm)

Soot Concentration $(\mathrm{mg} / \mathrm{m} 3$

SOF (mg/bhp-hr)

Soot (mg/bhp-hr)

Estimated PM (mg/bhp-hr)

\begin{tabular}{|c|c|c|c|c|c|}
\hline 2 & 3 & 4 & 5 & 6 & 7 \\
\hline 1799.04 & 1799.04 & 1799.05 & 2400.41 & 2400.42 & 2400.44 \\
\hline 37.84 & 75.04 & 131.95 & 152.87 & 40.73 & 82.03 \\
\hline 0.22 & 0.43 & 0.75 & 1.16 & 0.31 & 0.62 \\
\hline 0.00 & 0.00 & 0.00 & 0.00 & 0.00 & 0.00 \\
\hline 1.11 & 0.32 & 0.38 & 0.10 & 0.61 & 0.29 \\
\hline 0.9988 & 0.9993 & 1.0000 & 0.9992 & 0.9980 & 0.9973 \\
\hline 0.01 & 0.05 & 0.05 & 0.11 & 0.02 & 0.05 \\
\hline 0.01 & 0.04 & 0.05 & 0.10 & 0.02 & 0.05 \\
\hline 1.76 & 6.86 & 4.06 & 5.64 & 3.49 & 5.27 \\
\hline 1.57 & 6.13 & 3.66 & 4.91 & 3.06 & 4.64 \\
\hline 0.02 & 0.02 & 0.35 & 0.29 & 0.02 & 0.00 \\
\hline 2.24 & 3.93 & 7.14 & 10.48 & 3.17 & 5.57 \\
\hline 621.85 & 550.99 & 568.47 & 539.73 & 613.45 & 534.61 \\
\hline 5.86 & 2.31 & 27.84 & 15.02 & 2.97 & 0.36 \\
\hline 1242.67 & 1242.75 & 1242.58 & 1242.58 & 1242.55 & 1242.88 \\
\hline-0.01 & -0.01 & -0.01 & -0.01 & -0.01 & -0.01 \\
\hline-0.03 & -0.03 & -0.03 & -0.03 & -0.03 & -0.03 \\
\hline 43.07 & 74.80 & 145.21 & 206.26 & 60.45 & 105.28 \\
\hline 53.28 & 59.59 & 79.44 & 118.07 & 60.35 & 83.59 \\
\hline 0.00 & 0.00 & 0.00 & 0.00 & 0.00 & 0.00 \\
\hline 38.78 & 0.01 & 0.01 & 0.01 & 3.48 & 0.01 \\
\hline 16.99 & 20.60 & 20.60 & 20.60 & 20.31 & 20.60 \\
\hline 11.28 & 9.66 & 3.22 & 4.43 & 12.37 & 11.26 \\
\hline 3.39 & 6.73 & 11.83 & 13.71 & 3.65 & 7.36 \\
\hline 393.38 & 247.60 & 295.61 & 113.35 & 295.17 & 207.10 \\
\hline 139.81 & 935.25 & 731.14 & 1058.37 & 343.27 & 749.74 \\
\hline 754.04 & 531.54 & 8442.30 & 4783.86 & 487.80 & 90.30 \\
\hline 58826.06 & 86221.09 & 112512.20 & 109439.60 & 70188.63 & 84617.09 \\
\hline 0.11 & 3.68 & 68.69 & 62.28 & 0.22 & 1.20 \\
\hline 0.98 & 13.97 & 337.24 & 175.02 & 1.37 & 5.09 \\
\hline 0.86 & 17.39 & 269.14 & 242.00 & 1.41 & 5.41 \\
\hline 1.83 & 31.36 & 606.38 & 417.02 & 2.78 & 10.51 \\
\hline
\end{tabular}


Type: Steady-State

Test ID: 0030-002-06

Test Started: 2011-11-12 15:30:56

Program Version: 1.0.4333.21901

Comments: Hot Start 7-mode; Haltermann

*mode 1 was used for calibration and data was not use

Mode

Average Speed (rpm)

Average Torque (ft-lb)

Total Work (bhp-hr)

$\mathrm{HC}(\mathrm{g} / \mathrm{s})$

$\mathrm{HC}(\mathrm{g} / \mathrm{bhp}-\mathrm{hr})$

$\mathrm{Kh}$

$\mathrm{NOx}(\mathrm{g} / \mathrm{s})$

Secondary NOx (g/s)

NOx (g/bhp-hr)

Secondary NOx (g/bhp-hr)

$\mathrm{CO}(\mathrm{g} / \mathrm{s})$

$\mathrm{CO} 2(\mathrm{~g} / \mathrm{s})$

$\mathrm{CO} 2$ (g/bhp-hr)

CO (g/bhp-hr)

Gaseous VMix (scf)

Secondary Dilution Flow (scf)

Total PM Flow (scf)

Fuel Mass Carbon Balance (g)

Intake Air Volume (scf)

Fuel Mass Gravimetric (g)

EGR Fraction (\%)

Intake $\mathrm{O} 2(\%)$

Exhaust $\mathrm{O} 2$ (\%)

BMEP (bar)

Engine $\mathrm{HC}$ (ppm)

Engine NOx (ppm)

Engine CO (ppm)

$\mathrm{CO} 2$ (ppm)

Soot Concentration $(\mathrm{mg} / \mathrm{m} 3$

SOF (mg/bhp-hr)

Soot (mg/bhp-hr)

Estimated PM (mg/bhp-hr)

2

1799.04

37.89

0.22

0.00

1.07

0.9985

0.01

1.94

0.01

1.75

0.02

5.39

2.23

617.99

1243.76

$-0.01$

$-0.03$

53.40

42.81

0.00

36.62

17.19

11.30

3.40

377.96

152.28

697.05

58449.14

0.11

1.00

0.92

1.92

3

1799.04

74.79

0.43

0.00

0.35

0.9969

0.05

7.15

0.05

6.34

0.01

1.95

3.92

551.05

1242.43

$-0.01$

$-0.03$

59.99

74.50

0.00

0.01

20.60

9.82

6.71

250.32

965.66

448.39

85363.70

2.98

11.58

14.17

25.75

4

1799.05

132.20

0.75

0.00

0.35

1.0008

0.05

4.00

0.04

3.54

0.36

28.49

7.19

571.96

1242.17

$-0.01$

$-0.03$

79.33

146.53

0.00

0.01

20.60

2.99

11.85

274.15

721.38

8676.93

113536.60

75.85

345.40

298.16

643.56
5

2400.41

153.14

1.17

0.00

0.10

0.9967

0.10

$$
5.34
$$

0.09

4.59

0.33

16.94

10.60

545.18

1242.24

$-0.01$

$-0.03$

118.18

209.73

0.00

0.01

20.60

3.88

13.73

109.25

1005.75

5400.12

110567.30

76.1

209.41

298.70

508.11

\begin{tabular}{rr}
6 & \multicolumn{1}{c}{7} \\
2400.42 & 2400.44 \\
41.01 & 82.15 \\
0.31 & 0.63 \\
0.00 & 0.00 \\
0.64 & 0.32 \\
0.9966 & 0.9962
\end{tabular}

$0.02 \quad 0.06$

$3.52 \quad 5.29$

$0.02 \quad 0.05$

$3.07 \quad 4.61$

$0.01 \quad 0.00$

$2.85 \quad 0.36$

$3.18 \quad 5.59$

$611.35 \quad 535.94$

$1243.05 \quad 1242.75$

$-0.01 \quad-0.01$
-0.03

$\begin{array}{ll}-0.03 & -0.03\end{array}$

$60.65 \quad 83.93$

$60.65 \quad 105.70$

$0.00 \quad 0.00$

$3.23 \quad 0.01$

$20.33 \quad 20.60$

$12.31 \quad 11.28$

$\begin{array}{ll}3.68 & 7.37\end{array}$

$299.86 \quad 213.91$

$346.45 \quad 750.63$

$473.53 \quad 92.34$

$70044.13 \quad 84564.51$

$\begin{array}{ll}0.24 & 1.20\end{array}$

$1.50 \quad 5.34$

$1.52 \quad 5.46$

$3.02 \quad 10.80$ 
Type: Steady-State

Test ID: 0030-002-07

Test Started: 2011-11-12 15:57:56

Program Version: 1.0.4333.21901

Comments: Hot Start 7-mode; Haltermann

*mode 1 was used for calibration and data was not use

Mode

Average Speed (rpm)

Average Torque (ft-lb)

Total Work (bhp-hr)

$\mathrm{HC}(\mathrm{g} / \mathrm{s})$

$\mathrm{HC}(\mathrm{g} / \mathrm{bhp}-\mathrm{hr})$

$\mathrm{Kh}$

$\mathrm{NOx}(\mathrm{g} / \mathrm{s})$

Secondary NOx (g/s)

NOx (g/bhp-hr)

Secondary NOx (g/bhp-hr)

$\mathrm{CO}(\mathrm{g} / \mathrm{s})$

$\mathrm{CO} 2(\mathrm{~g} / \mathrm{s})$

$\mathrm{CO} 2$ (g/bhp-hr)

$\mathrm{CO}$ (g/bhp-hr)

Gaseous VMix (scf)

Secondary Dilution Flow (scf)

Total PM Flow (scf)

Fuel Mass Carbon Balance (g)

Intake Air Volume (scf)

Fuel Mass Gravimetric (g)

EGR Fraction (\%)

Intake $\mathrm{O} 2(\%)$

Exhaust 02 (\%)

BMEP (bar)

Engine $\mathrm{HC}$ (ppm)

Engine NOx (ppm)

Engine CO (ppm)

$\mathrm{CO} 2$ (ppm)

Soot Concentration $(\mathrm{mg} / \mathrm{m} 3$

SOF (mg/bhp-hr)

Soot (mg/bhp-hr)

Estimated PM (mg/bhp-hr)

\begin{tabular}{rrrrrr}
\multicolumn{1}{c}{2} & \multicolumn{1}{c}{3} & \multicolumn{1}{c}{4} & \multicolumn{1}{c}{5} & \multicolumn{1}{c}{6} & \multicolumn{1}{c}{7} \\
1799.06 & 1799.06 & 1799.07 & 2400.44 & 2400.46 & 2400.49 \\
74.59 & 38.10 & 131.97 & 152.43 & 81.97 & 41.01 \\
0.43 & 0.22 & 0.75 & 1.16 & 0.62 & 0.31 \\
0.00 & 0.00 & 0.00 & 0.00 & 0.00 & 0.00 \\
0.33 & 0.99 & 0.31 & 0.09 & 0.32 & 0.65 \\
0.9960 & 0.9958 & 0.9966 & 0.9942 & 0.9955 & 0.9956
\end{tabular}

\subsection{5}

7.11

0.04

6.28

0.01

2.11

3.91

551.39

1242.73

$-0.01$

$-0.03$

60.02

74.37

0.00

0.01

20.60

9.90

6.69

246.75

958.94

479.61

85215.48

3.16

12.19

15.12

27.31
0.01

1.99

0.01

1.77

0.02

5.13

2.24

617.77

1242.60

$-0.01$

$-0.03$

53.00

43.00

0.00

35.14

17.30

11.24

3.42

365.64

159.73

670.05

59196.59

0.11

0.94

0.89

1.82
0.05

3.96

0.04

3.51

0.36

28.75

7.20

573.21

1242.84

$-0.01$

$-0.03$

79.56

146.64

0.00

0.01

20.60

2.98

11.83

254.32

715.31

8699.21

113245.30

79.55

338.86

314.68

653.54

$$
0.11
$$

5.50

0.09

4.73

0.30

15.57

10.50

542.54

1243.22

$-0.01$

$-0.03$

118.07

207.00

0.00

0.01

20.60

4.22

13.67

105.08

1034.20

4941.72

109658.20

66.70

174.49

261.62

436.10

\section{$\begin{array}{ll}0.05 & 0.02\end{array}$}

$\begin{array}{ll}5.28 & 3.57\end{array}$

$0.05 \quad 0.02$

$4.60 \quad 3.10$

$0.00 \quad 0.01$

$\begin{array}{ll}0.38 & 2.74\end{array}$

5.58

3.19

536.13

1243.12

$-0.01$

$-0.03$

83.91

105.51

0.00

0.01

20.60

11.23

7.35

216.21

748.43

93.90

84473.02

1.08

4.85

4.92

9.77
612.62

1243.08

$-0.01$

$-0.03$

60.72

60.77

0.00

3.10

20.34

12.27

3.68

307.00

351.75

451.99

70147.55

0.27

1.70

1.68

3.38 
Type: Steady-State

Test ID: 0030-004-02

Test Started: 2011-11-13 05:37:16

Program Version: 1.0.4333.21901

Comments: Hot Start 7-mode; Haltermann

*mode 1 was used for calibration and data was not use

Mode

Average Speed (rpm)

Average Torque (ft-lb)

Total Work (bhp-hr)

$\mathrm{HC}(\mathrm{g} / \mathrm{s})$

$\mathrm{HC}$ (g/bhp-hr)

$\mathrm{Kh}$

$\mathrm{NOx}(\mathrm{g} / \mathrm{s})$

Secondary NOx (g/s)

NOx (g/bhp-hr)

Secondary NOx (g/bhp-hr)

$\mathrm{CO}(\mathrm{g} / \mathrm{s})$

$\mathrm{CO} 2(\mathrm{~g} / \mathrm{s})$

$\mathrm{CO} 2$ (g/bhp-hr)

$\mathrm{CO}$ (g/bhp-hr)

Gaseous VMix (scf)

Secondary Dilution Flow (scf)

Total PM Flow (scf)

Fuel Mass Carbon Balance (g)

Intake Air Volume (scf)

Fuel Mass Gravimetric (g)

EGR Fraction (\%)

Intake $\mathrm{O} 2$ (\%)

Exhaust $\mathrm{O} 2$ (\%)

BMEP (bar)

Engine $\mathrm{HC}$ (ppm)

Engine NOx (ppm)

Engine CO (ppm)

$\mathrm{CO} 2$ (ppm)

Soot Concentration $(\mathrm{mg} / \mathrm{m} 3$

SOF (mg/bhp-hr)

Soot (mg/bhp-hr)

Estimated PM (mg/bhp-hr)

\begin{tabular}{rrrrrr}
\multicolumn{1}{c}{2} & \multicolumn{1}{c}{3} & \multicolumn{1}{c}{4} & \multicolumn{1}{c}{5} & \multicolumn{1}{c}{6} & \multicolumn{1}{c}{7} \\
1799.15 & 1799.17 & 1799.18 & 2400.54 & 2400.56 & 2400.58 \\
38.04 & 74.39 & 133.80 & 153.63 & 40.91 & 81.85 \\
0.22 & 0.42 & 0.76 & 1.17 & 0.31 & 0.62 \\
0.00 & 0.00 & 0.01 & 0.00 & 0.00 & 0.00 \\
1.23 & 0.67 & 0.71 & 0.21 & 0.47 & 0.28 \\
0.9999 & 1.0040 & 0.9995 & 1.0017 & 1.0005 & 1.0000
\end{tabular}

0.01

3.08

0.01

3.07

0.01

3.37

2.30

635.27

1242.57

$-0.01$

$-0.03$

53.14

43.99

0.00

13.52

19.40

11.71

3.41

465.18

241.09

439.99

60675.02

25.79

272.97

202.90

475.87
0.04

4.98

0.04

5.02

0.02

2.76

4.38

618.72

1241.92

$-0.01$

$-0.03$

69.64

83.44

0.00

0.01

20.60

12.04

6.67

368.76

573.52

538.21

81634.59

13.79

107.71

77.15

184.86
0.05

4.18

0.05

4.21

0.14

10.62

7.66

601.39

1242.11

$-0.01$

$-0.03$

80.68

148.91

0.00

0.01

20.60

5.34

12.00

510.66

751.46

3224.54

118662.30

20.20

177.10

79.36

256.45
0.08

4.34

0.09

4.36

0.30

15.46

12.31

631.14

1243.78

$-0.01$

$-0.03$

117.20

241.29

0.00

0.01

20.60

2.04

13.78

193.74

823.50

5011.74

12920230

87.62

447.28

363.74

811.02
$0.02 \quad 0.05$

$3.58 \quad 4.65$

$0.02 \quad 0.05$

$3.58 \quad 4.67$

$0.01 \quad 0.01$

$2.11 \quad 0.86$

3.26

628.43

1243.12

$-0.01$

$-0.03$

65.98

62.02

0.00

0.01

20.60

11.41

3.67

262.42

321.64

320.15

$66142.98 \quad 77632.27$

\subsection{6}

8.83

9.38

18.20
6.62

637.18

1242.24

$-0.01$

$-0.03$

107.47

125.29

0.00

0.01

20.60

12.23

7.34

175.07

511.62

160.94

0.68

4.14

4.04

8.18 
Type: Steady-State

Test ID: 0030-004-03

Test Started:

Program Version: 1.0.4333.21901

Comments: Hot Start 7-mode; Haltermann

*mode 1 was used for calibration and data was not use

Mode

Average Speed (rpm)

Average Torque (ft-lb)

Total Work (bhp-hr)

$\mathrm{HC}(\mathrm{g} / \mathrm{s})$

$\mathrm{HC}(\mathrm{g} / \mathrm{bhp}-\mathrm{hr})$

$\mathrm{Kh}$

NOx $(\mathrm{g} / \mathrm{s})$

Secondary NOx (g/s)

NOx (g/bhp-hr)

Secondary NOx (g/bhp-hr)

$\mathrm{CO}(\mathrm{g} / \mathrm{s})$

$\mathrm{CO} 2(\mathrm{~g} / \mathrm{s})$

$\mathrm{CO} 2$ (g/bhp-hr)

$\mathrm{CO}$ (g/bhp-hr)

Gaseous VMix (scf)

Secondary Dilution Flow (scf)

Total PM Flow (scf)

Fuel Mass Carbon Balance (g)

Intake Air Volume (scf)

Fuel Mass Gravimetric (g)

EGR Fraction (\%)

Intake 02 (\%)

Exhaust $\mathrm{O} 2$ (\%)

BMEP (bar)

Engine $\mathrm{HC}$ (ppm)

Engine NOx (ppm)

Engine CO (ppm)

$\mathrm{CO} 2$ (ppm)

Soot Concentration $(\mathrm{mg} / \mathrm{m} 3$

SOF (mg/bhp-hr)

Soot ( $\mathrm{mg} / \mathrm{bhp}-\mathrm{hr}$ )

Estimated PM (mg/bhp-hr)

\begin{tabular}{rrrrrr}
\multicolumn{1}{c}{2} & \multicolumn{1}{c}{3} & \multicolumn{1}{c}{4} & \multicolumn{1}{c}{5} & \multicolumn{1}{c}{6} & \multicolumn{1}{c}{7} \\
1799.15 & 1799.17 & 1799.18 & 2400.54 & 2400.56 & 2400.58 \\
38.04 & 74.39 & 133.80 & 153.63 & 40.91 & 81.85 \\
0.22 & 0.42 & 0.76 & 1.17 & 0.31 & 0.62 \\
0.00 & 0.00 & 0.01 & 0.00 & 0.00 & 0.00 \\
1.23 & 0.67 & 0.71 & 0.21 & 0.47 & 0.28 \\
0.9999 & 1.0040 & 0.9995 & 1.0017 & 1.0005 & 1.0000
\end{tabular}

$\begin{array}{rrrrrr}0.01 & 0.04 & 0.05 & 0.08 & 0.02 & 0.05 \\ 3.08 & 4.98 & 4.18 & 4.34 & 3.58 & 4.65 \\ 0.01 & 0.04 & 0.05 & 0.09 & 0.02 & 0.05 \\ 3.07 & 5.02 & 4.21 & 4.36 & 3.58 & 4.67 \\ 0.01 & 0.02 & 0.14 & 0.30 & 0.01 & 0.01 \\ 3.37 & 2.76 & 10.62 & 15.46 & 2.11 & 0.86 \\ 2.30 & 4.38 & 7.66 & 12.31 & 3.26 & 6.62 \\ 635.27 & 618.72 & 601.39 & 631.14 & 628.43 & 637.18 \\ 242.57 & 1241.92 & 1242.11 & 1243.78 & 1243.12 & 1242.24 \\ -0.01 & -0.01 & -0.01 & -0.01 & -0.01 & -0.01 \\ -0.03 & -0.03 & -0.03 & -0.03 & -0.03 & -0.03\end{array}$

$\begin{array}{llllll}53.14 & 69.64 & 80.68 & 117.20 & 65.98 & 107.47\end{array}$

$\begin{array}{llllll}43.99 & 83.44 & 148.91 & 241.29 & 62.02 & 125.29\end{array}$

$\begin{array}{llllll}0.00 & 0.00 & 0.00 & 0.00 & 0.00 & 0.00\end{array}$

$\begin{array}{llllll}13.52 & 0.01 & 0.01 & 0.01 & 0.01 & 0.01\end{array}$

$\begin{array}{llllll}19.40 & 20.60 & 20.60 & 20.60 & 20.60 & 20.60\end{array}$

$\begin{array}{llllll}11.71 & 12.04 & 5.34 & 2.04 & 11.41 & 12.23\end{array}$

$\begin{array}{llllll}3.41 & 6.67 & 12.00 & 13.78 & 3.67 & 7.34\end{array}$

$\begin{array}{llllll}465.18 & 368.76 & 510.66 & 193.74 & 262.42 & 175.07\end{array}$

$\begin{array}{llllll}241.09 & 573.52 & 751.46 & 823.50 & 321.64 & 511.62\end{array}$

$\begin{array}{lrrrrr}439.99 & 538.21 & 3224.54 & 5011.74 & 320.15 & 160.94\end{array}$

$\begin{array}{llllll}60675.02 & 81634.59 & 118662.30 & 129202.30 & 66142.98 & 77632.27\end{array}$

$\begin{array}{llllll}25.79 & 13.79 & 20.20 & 87.62 & 1.36 & 0.68\end{array}$

$\begin{array}{llllll}272.97 & 107.71 & 177.10 & 447.28 & 8.83 & 4.14\end{array}$

$\begin{array}{llllll}202.90 & 77.15 & 79.36 & 363.74 & 9.38 & 4.04\end{array}$

$\begin{array}{llllll}475.87 & 184.86 & 256.45 & 811.02 & 18.20 & 8.18\end{array}$ 
Type: Steady-State

Test ID: 0030-004-03

Test Started:

Program Version: 1.0.4333.21901

Comments: Hot Start 7-mode; Haltermann

*mode 1 was used for calibration and data was not use

Mode

Average Speed (rpm)

Average Torque (ft-lb)

Total Work (bhp-hr)

$\mathrm{HC}(\mathrm{g} / \mathrm{s})$

$\mathrm{HC}(\mathrm{g} / \mathrm{bhp}-\mathrm{hr})$

$\mathrm{Kh}$

$\mathrm{NOx}(\mathrm{g} / \mathrm{s})$

Secondary NOx (g/s)

NOx (g/bhp-hr)

Secondary NOx (g/bhp-hr)

$\mathrm{CO}(\mathrm{g} / \mathrm{s})$

$\mathrm{CO} 2(\mathrm{~g} / \mathrm{s})$

$\mathrm{CO} 2$ (g/bhp-hr)

CO (g/bhp-hr)

Gaseous VMix (scf)

Secondary Dilution Flow (scf)

Total PM Flow (scf)

Fuel Mass Carbon Balance (g)

Intake Air Volume (scf)

Fuel Mass Gravimetric (g)

EGR Fraction (\%)

Intake $\mathrm{O} 2(\%)$

Exhaust $\mathrm{O} 2$ (\%)

BMEP (bar)

Engine $\mathrm{HC}$ (ppm)

Engine NOx (ppm)

Engine CO (ppm)

$\mathrm{CO} 2$ (ppm)

Soot Concentration $(\mathrm{mg} / \mathrm{m} 3$

SOF (mg/bhp-hr)

Soot (mg/bhp-hr)

Estimated PM (mg/bhp-hr)

\begin{tabular}{rrrrrr}
\multicolumn{1}{c}{2} & \multicolumn{1}{c}{3} & \multicolumn{1}{c}{4} & \multicolumn{1}{c}{5} & \multicolumn{1}{c}{6} & \multicolumn{1}{c}{7} \\
1799.12 & 1799.13 & 1799.13 & 2400.53 & 2400.55 & 2400.56 \\
37.83 & 133.48 & 75.42 & 154.09 & 81.96 & 40.86 \\
0.22 & 0.76 & 0.43 & 1.17 & 0.62 & 0.31 \\
0.00 & 0.01 & 0.00 & 0.00 & 0.00 & 0.00 \\
1.02 & 0.82 & 0.61 & 0.22 & 0.26 & 0.49 \\
1.0029 & 1.0023 & 1.0010 & 1.0021 & 0.9999 & 0.9999
\end{tabular}

$\begin{array}{llllll}0.01 & 0.05 & 0.04 & 0.08 & 0.05 & 0.02\end{array}$

$\begin{array}{llllll}2.99 & 4.17 & 4.94 & 4.06 & 4.55 & 3.55\end{array}$

$\begin{array}{llllll}0.01 & 0.05 & 0.04 & 0.08 & 0.05 & 0.02\end{array}$

$\begin{array}{llllll}3.03 & 4.21 & 5.00 & 4.08 & 4.58 & 3.59\end{array}$

$\begin{array}{llllll}0.01 & 0.13 & 0.02 & 0.43 & 0.01 & 0.01\end{array}$

$\begin{array}{llllll}3.33 & 10.55 & 2.72 & 21.81 & 0.79 & 2.13\end{array}$

$\begin{array}{llllll}2.27 & 7.62 & 4.39 & 12.34 & 6.65 & 3.25\end{array}$

$\begin{array}{llllll}630.58 & 599.70 & 611.00 & 630.86 & 638.84 & 626.80\end{array}$

$\begin{array}{llllll}1242.22 & 1241.65 & 1241.54 & 1243.52 & 1244.28 & 1242.11\end{array}$

$\begin{array}{llllll}-0.01 & -0.01 & -0.01 & -0.01 & -0.01 & -0.01\end{array}$

$\begin{array}{llllll}-0.03 & -0.03 & -0.03 & -0.03 & -0.03 & -0.03\end{array}$

$\begin{array}{llllll}52.48 & 80.48 & 70.34 & 116.97 & 107.89 & 65.87\end{array}$

$\begin{array}{llllll}43.37 & 148.21 & 83.52 & 245.61 & 125.75 & 61.79\end{array}$

$\begin{array}{llllll}0.00 & 0.00 & 0.00 & 0.00 & 0.00 & 0.00\end{array}$

$\begin{array}{llllll}14.97 & 0.01 & 0.01 & 0.01 & 0.02 & 0.01\end{array}$

$\begin{array}{llllll}19.31 & 20.60 & 20.60 & 20.60 & 20.60 & 20.60\end{array}$

$\begin{array}{llllll}12.02 & 5.30 & 11.92 & 1.07 & 12.33 & 11.56\end{array}$

$\begin{array}{llllll}3.39 & 11.97 & 6.76 & 13.82 & 7.35 & 3.66\end{array}$

$\begin{array}{llllll}417.67 & 576.62 & 347.05 & 202.46 & 169.49 & 267.67\end{array}$

$\begin{array}{llllll}236.43 & 748.96 & 574.68 & 776.02 & 500.54 & 320.48\end{array}$

$\begin{array}{lrrrrr}443.06 & 3204.87 & 536.86 & 7105.98 & 151.62 & 327.29\end{array}$

$\begin{array}{llllll}60986.44 & 118523.10 & 81038.33 & 129865.80 & 77723.84 & 66179.64\end{array}$

$\begin{array}{llllll}19.58 & 21.97 & 12.23 & 104.15 & 0.77 & 1.12\end{array}$

$\begin{array}{llllll}182.00 & 211.33 & 90.30 & 555.31 & 4.57 & 7.42\end{array}$

$\begin{array}{llllll}153.08 & 86.41 & 68.16 & 431.80 & 4.60 & 7.73\end{array}$

$\begin{array}{llllll}335.07 & 297.74 & 158.46 & 987.10 & 9.16 & 15.15\end{array}$ 